\title{
Çelik Çekirdekli Burkulması Önlenmiş Çaprazların (BÖÇ) Tasarımı, Üretimi ve Deneysel İncelenmesi
}

\author{
Çiğdem AVCI KARATAŞ ${ }^{1}$ \\ Ŏguz Cem ÇELÍk
}

ÖZ

Bir tür metalik sönümleyiciler olarak kabul edilen Burkulması önlenmiş Çaprazlar (BÖÇ) önemli depremlerde çekme ve basınçta akarak dengeli bir histeretik davranış gösterirler. Bu çalışmada farklı çelik uç detayı malzemesine sahip BÖÇ’lerin yön değiştiren tekrarlı yükler altındaki histeretik davranışına ilişkin deneysel bulgu ve değerlendirmeleri verilmektir. Denenen BÖÇ'ler için kuvvet-yerdeğiştirme histeretik eğrileri, histeretik enerji yutma miktarları ve etkili sönüm oranları hesaplanarak karşılaştırmalar yapılmıştır. Özgün detaylar ile üretilen ve denenen BÖÇ'lerin yeterli bir performans gösterdiği ve bu performansının ileride yapılabilecek çalışmalarla iyileştirilebileceği sonucuna varılmıştır.

Anahtar Kelimeler: Çelik, burkulması önlenmiş çapraz (BÖÇ), histeretik enerji, etkili sönüm oran1.

\section{ABSTRACT \\ Design, Fabrication, and Experimental Investigation of Steel Core Buckling Restrained Braces (BRBS)}

Buckling restrained braces (BRBs), being a sort of metallic damper, display a balanced hysteretic behavior by yielding under tension and compression forces during major earthquakes. The study presents experimental findings and evaluations from hysteretic behaviors of BRBs having different steel core material and end connection details under reversed cyclic displacements. For the tested BRBs, force-displacement hysteretic curves, dissipated hysteretic energies, and effective damping ratios obtained from hysteretic curves are calculated and compared. Experimental results reveal that the BRBs developed here with unique details display sufficient performance and this performance could be improved by similar forthcoming studies.

Keywords: Steel, buckling restrained brace (BRB), hysteretic energy, effective damping ratio.

\footnotetext{
Not: Bu yazı

- Yayın Kurulu’na 20 Nisan 2017 günü ulaşmıştır. 16 Mart 2018 günü yayımlanmak üzere kabul edilmiștir.

- 31 Mart 2019 gününe kadar tartı̧̧maya açıktır.

- DOI: $10.18400 /$ tekderg.309415
}

1 Yalova Üniversitesi, Ulaştırma Mühendisliği Bölümü, Yalova - cigdem.karatas@hotmail.com

2 İstanbul Teknik Üniversitesi, Mimarlık Bölümü, İstanbul - celikoguz@itu.edu.tr 


\section{GİRIŞ}

Burkulması önlenmiş çaprazlar (BÖÇ) dengeli ve dolu histeretik özellikleri nedeniyle mevcut çelik ve betonarme iskeletli binaların rijitlik, dayanım ve sünekliklerinin arttırılması için güçlendirme amacıyla, yeni binalarda etkin enerji yutma elemanı olarak kullanılabilmektedir. Köprülerdeki kullanımı ise özellikle sünek enerji yutma elemanları olarak (örneğin uç diyaframlarda) çoğunlukla Japonya ve ABD'de yaygınlaşmaktadır. BÖÇ'lerin çekme ve basınçta yaklaşık simetrik davranış göstermesi, rijitlik ve dayanım kaybı göstermeden aynı zamanda stabil histeretik eğrilerin elde edilmesi kullanım alanını genişletmiştir. Tipik bir BÖÇ genellikle dört parçadan oluşmaktadır: Burkulması önlenen ve eksenel kuvveti taşıyan çelik çubuk "çekirdek eleman", çekirdek elemanın burkulmasını önleyen ve ekseni doğrultusunda çok küçük ya da sıfır yük alan dış eleman ise "dış tüp" olarak isimlendirilmektedir. BÖÇ’ün diğer bileşenleri ise diş tüple birlikte burkulmayı önleyen sistemi oluşturan "dolgu malzemesi (yüksek/normal dayanımlı tamir harc1)" ve çekirdek eleman ile dolgu malzemesi arasında görev yapan "sürtünmesiz yüzey malzemesi” dir. BÖÇ davranışını belirleyen, çekirdek elemanın geometrik yapısıdır. Çekirdek eleman üç bölgeye ayrılmıştır: Elastik olmayan şekildeğiştirmelerin oluşmasının istenildiği "akma bölgesi", akma bölgesine göre daha geniş enkesiti olan ve çekirdek elemanın tutulu uzunluğu dışında yerel burkulma yapmasına engel olan "güçlendirme bölgesi" ve ana çerçeveye bağlantının yapıldığı, dolgu malzemeli dış tüpün dışında kalan "birleşim bölgesi” dir. BÖÇ'lere ilişkin öncü deneysel çalışmalar Japonya'da Wakabayashi ve diğ. [1] tarafindan yapılmış olup çelik düz plakadan üretilmiş çaprazı bir çift prekast betonarme panel arasına yerleştirip ve aralarında sürtünmesiz yüzey tabakası bırakarak "Sandviç Model” adı verilen bir sistem geliştirmişlerdir. Çelik çaprazın dolgulu çelik dış tüple zırhlandığı ilk deneysel çalışmalar ise Kimura ve diğ. [2] tarafından yapılmıştır. Watabane ve diğ. [3], çaprazın tümsel burkulma davranışı üzerine yaptıkları çalışmalarda dış tüpün Euler burkulma yükü $P_{e}$, çekirdek elemanın eksenel akma yükü $P_{y}$ olmak üzere $P_{e} / P_{y}$ oranları elde edilmiştir $(0.55 \leq$ $\left.P_{e} / P_{y} \leq 3.53\right)$. Sonuçta, başlangıçtaki geometrik kusurların büyüklüğünün tümsel burkulmaların oluşmasına etkisi olduğu ve bu yüzden uygulamada $P_{e} / P_{y}$ oranın en az 1.5 alınması gerektiği önerilmiştir. Ghedi ve diğ. [4], çelik çekirdek elemanı ile dış tüp arasında bulunan dolgu malzemesinin BÖÇ’ün davranışı üzerine etkisini anlamak için yapmış oldukları BÖÇ'lü eksenel yükleme deneylerinde dolgu malzemesi olarak normal beton, hafif beton ve sıkıştırılmış agrega kullanmışlardır. Sonuçta, 28 günlük basınç dayanımı 25 30MPa olan normal betonun dikdörtgen kesitli çekirdek plakanın yerel ve tümsel burkulmalarını önlemek için yeterli ve güvenilir olduğunu görmüşlerdir. Berman ve Bruneau [5], bayrak plakası performansının BÖÇ’'lü çerçeve sistemlerinin performansına ve sistemin davranışına etkisini incelemişlerdir. Bayrak plakasıyla kolon-kiriş bağlantısı olan bir çerçeve, olmayan çerçeveye göre daha rijittir. Sistemin rijitliği arttıkça titreşim periyodu kısalırken yatay deprem kuvveti istemi/talebi artmaktadır. Rijit bayrak plakaları BÖÇ’lere eğilme momenti aktarabildiğinden toplam inelastik eksenel şekildeğiştirme kapasitesini azaltabilmektedir. Bazı davranışsal (örneğin birleşim kaynaklarının yorulması gibi) olumsuzluklardan kaçınmak için bayrak plakası tasarlarken plakanın kolon yerine yalnızca kirişe bağlanması da önerilmiştir. Çelik ve diğ. [6] çaprazlı çelik çerçevelerin yön değiştiren tekrarlı yükler altında performanslarını deneysel olarak incelemişlerdir. Çoğunlukla tıknaz çaprazların performanslarının narin olanlara göre daha iyi olduğu düşünüldüğünden, çaprazların narinliklerinin soğukta şekil verilmiş çelik dikmelerden oluşan mimari elemanlarla azaltılması yoluna gidilmiş, böylece bir tür BÖÇ elde edilmiştir. Çalışmada 
çaprazların burkulması yeterince önlenmiş ve daha dolu histeretik eğrilere ulaşılmıştır. Çelik ve Bruneau [7] iki doğrultuda düzenlenen BÖÇ'lerin sünek enerji yutma elemanları olarak verev köprülerin uç diyaframlarında kullanılmasını ilk kez önermiştir. Son yıllarda çelik BÖÇ’lere ilişkin yapılan deneysel çalışmalar stabilite (örneğin burkulma, uç birleşim) sorunlarının iyileştirilmesi ve mevcut betonarme yapıların (bina, köprü) BÖÇ’lerle güçlendirilmesi üzerinde yoğunlaşmaktadır. Zhao ve diğ. [8] çelik dört köşebentten oluşturulmuş haçvari çekirdek elemanlı 8 adet BÖÇ’ün yerel stabilitesini deneysel ve kuramsal yöntemlerle araştırmışlardır. Yerel burkulma ve histeretik davranıştaki dayanım kayıplarının özellikle köşebent enkesit oranının $(b / t)$ yaklaşık 8.5 olduğu BÖÇ’lerde gerçekleştiği, enkesit oranı azaltılarak çekirdeğin yerel burkulmasının azaltılacağı ve böylelikle stabil histeretik performansın arttırılacağı sonucu elde edilmiştir. BÖÇ'lerde tümsel burkulma olasılığına uç birleşimlerin ve düzlem dışı yerdeğişitrmelerin etkisi Takeuchi ve diğ. [9] tarafından araştırılmıştır. Gerçeğe yakın ölçeklerde kaynaklı ve bulonlu uç birleşimli BÖÇ’lerin histeretik yön değiştiren yükler altında deneyleri Fujishita ve diğ. [10] gerçekleştirilmiş ve karşılaştırmalı sonuçları verilmiştir. 1950-1970 yılları arasında Kuzeybatı Pasifik'te üretilen betonarme köprü ayaklarının BÖÇ kullanılarak güçlendirilmesi durumuna yönelik deneysel çalışmalara ilişkin bulgular Bazaez ve Dusicka [11] tarafından sunulmuştur. BÖÇ'lerle güçlendirme yapılması durumunda betonarme köprülerin yerdeğiştirme sünekliğinin 8'e kadar çıkabildiği, kolon ve kirişlerde çatlama ve plastik mafsal oluşumun kontrollü olduğu, böylelikle deprem davranışlarının iyileştiği gözlenmiştir. Chou ve diğ. [12] çift çekirdekli ve merkezlenme davranışı gösteren (self-centering) $7860 \mathrm{~mm}$ uzunluğunda ASTM A572Gr. 50 çelik malzemeli çekirdek elemanı olan BÖÇ’ün tasarım, üretimi ve histeretik davranışını deneysel olarak incelemişlerdir. Önerilen BÖÇ’ün enerji yutma miktarı, kendini merkezlenme özellikleri, yerdeğiştirme kapasiteleri özetlenmiştir. Türkiye'de BÖÇ konusunda yapılan deneysel çalışmalara verebileceğimiz örnekler şu şekildedir: Eryasar ve Topkaya [13] yapma/hadde çelik profillerin kaynaklı/bulonlu birleşimlerinden oluşturdukları burkulmayı önleyen ortamlı 12 adet BÖÇ numunesi ile deneysel bir çalışma gerçekleştirmişlerdir. Geliştirilen BÖÇ'lerin düzgün histeretik davranış sağladığını ve burkulmayı önleyen ortamların, çimento harcı doldurulmuş kutu profillerle oluşturulanlara alternatif olabileceğini göstermişlerdir. Bozkurt ve Topkaya [14] ilk aşamada sabit enkesitli çekirdekli BÖÇ’lerin eksenel ve diyagonal çaprazlama durumlarındaki davranış farklarını inceleyerek, bu çaprazların çekme ve basınç dayanımlarının kabul edilebilir sınırların üzerinde kaldığını görmüşlerdir. İkinci aşamada bu olumsuzluğu iyileştirmek için tasarlayarak ürettikleri kaynaklı bindirme çekirdekli BÖÇ’ün diyagonal çapraz deneylerini yapmışlardır. Yeni geliştirilen çekirdekli BÖÇ’ün toplam inelastik şekildeğiştirme değerinin akma şekildeğiştirme değerinin 419 katı olduğu ve ilk aşamadaki BÖÇ deneylerinde elde edilen histeretik eğrilerde \%2 olan maksimum eksenel şekildeğiştirme değerinin yeni tasarlanan BÖÇ için \%2.5'e yükseldiği görülmüştür. Ozcelik ve diğ. [15] ürettiklerin farklı enkesitli 10 adet BÖÇ'ün eksenel yükleme deneylerini gerçekleştirmişlerdir. Numunelerin bir bölümünde çimento harcı doldurulmuş çelik kutu enkesitli profiller kullanılırken, diğer bölümünde de sargısız beton ya da betonun FRP (lifli polimer) ile sarılmasıyla burkulmayı önleyici bir ortam oluşturulmuştur. Numunelerde uç dönmelerini önlemek ve uç stabilitesini arttırmak için ek çelik plaka ve profiller kullanılmıştır. Çevrimsel yüklemeler altında yaklaşık \%2 birim şekildeğiştirme oranına kadar numunelerden kararlı histeretik davranış elde edilmiştir. $\mathrm{Bu}$ deneysel çalışmada [13, 14, 15]'den farklı olarak uzunluk, enkesit, uç bağlantısı, burkulması önlenen ortam, sürtünmesiz yüzey teknikleri bakımından farklılıkları olan çelik BÖÇ’lerin çevrimsel yüklemeler altında 
diyagonal bir düzenekte deneyleri yapılmıştır. Üretilen BÖÇ'lerin en önemli özelliği daha az bileşenli olması ve fabrikasyona elverişliliğidir. Bu çalışmada farklı çelik malzemesine sahip BÖÇ’lerin yön değiştiren tekrarlı yükler altındaki histeretik davranışına ilişkin deneysel bulgu ve değerlendirmeler verilmektir. Bu amaçla tasarlanan ve üretilen toplam 5 adet çelik çekirdekli ve çelik dıș tüplü BÖÇ’ten ilk 3'ü “ön çalışmalar” olarak ele alınmıştır (BRB-SC1, $\mathrm{BRB}-\mathrm{SC} 2, \mathrm{BRB}-\mathrm{SC} 3)$. Ön çalışmalardan elde edilen bilgi ve deneyimler ışı̆̆ında tasarımı geliştirilen, üretimi yapılan ve İstanbul Teknik Üniversitesi, Yapı ve Deprem Mühendisliği Laboratuvarında (STEEL) yön değiştiren tekrarlı yükler altında denenen diğer 2 BÖÇ'ten (BRB-SC4 ve BRB-SC5) elde edilen deneysel bulgular çalışmanın ana bölümünü oluşturmaktadır. BRB-SC1, BRB-SC3 ve BRB-SC4 numuneleri S235JR normal akma dayanımlı, BRB-SC2 ve BRB-SC5 numuneleri S355JR yüksek akma dayanımlı çelik malzemesinden çekirdeği olan BÖÇ'lerdir; böylece farklı çelik malzemelerinin de davranışa olan etkisi incelenmiş olacaktır. BÖÇ'leri oluşturan çelik malzemelerinin mekanik çekme deneylerinden elde edilen sonuçlar açıklanmıştır. Çelik çekirdekli BÖÇ’ün tasarımı, üretimi, deney düzeneği ve numunelerin deneylerinde kullanılan ölçüm aletleri çalışma kapsamında verilmiştir. Denenen BÖÇ’lerin deney sonuçlarının değerlendirmesi yapılarak, elde edilen yatay kuvvet-yatay yerdeğiştirme histeretik davranış eğrileri, histeretik enerji grafikleri verilmiştir. BÖÇ’lerin etkili sönüm oranlarıda hesaplanarak karşılaştırılmıştır.

\section{MALZEME DENEYLERI}

\section{1. Çekme Deneyi Hazırıkları}

Tasarımı yapılan BÖÇ'lerin üretiminde kullanılan çelik malzemelerin (S235JR ve S355JR) mekanik özelliklerini tam olarak belirleyebilmek için çok sayıda çekme numunesi öngörülen standartlara göre ve çekirdek enkesit ölçülerine yakın boyutlarda hazırlanarak çekme deneyleri yapılmıştır. Deneysel çalı̧̧̧mada malzeme özelliklerinin belirlenmesinde ASTM A370-08a [16] standartlarına göre her plakadan olmak üzere toplam 9 adet çekme numunesi hazırlanmıştır. Çekme deneyleri İTÜ İnşaat Fakültesi, Yapı Malzemesi Laboratuvarında gerçekleştirilmiştir. Şekildeğiştirmelerin ölçülmesinde akma sonrası şekildeğiştirmeleri ölçen çelik yüzeye uyumlu YFLA-10-3L tipindeki şekildeğiştirme ölçerler (strain-gauge) kullanılmıştır. Çekme numuneleri fabrikada Sa-21/2 İsveç yöntemi ile kum püskürtülerek temizlenmiştir. Ancak bu temizleme yeterli bulunmayarak önce P320 kalın zımpara, sonra P120 ince zımpara yapılarak çelik yüzeyler parlak bir renk kazanıncaya kadar devam edilmiştir. Metal yüzeye yapıştırmak için tek bileşenli yapıştıııcılar kullanılmıştır. BÖÇ’lerin çekirdek üzerinden şekildeğiştirme ölçümlerinin yapılması için özel olarak metal yüzeyine açılan kanallara strain-gauge yerleştirilmiştir. Bu uygulama, bilindiği ve ulaşıldığı kadarıyla, BÖÇ teknolojisi için yeni bir ölçüm uygulaması olmuştur. Yapılan bu uygulamanın başarısını ölçmek için önceden hazırlanan her çekirdek çekme numunesine kullanılan strain-gauge ölçülerine uygun şekilde $\phi 2 \mathrm{~mm}$ 'lik parmak freze kullanılarak kanallar açılmıştır. Açılan kanallar içine önce bir tabaka yapıştırıcı ile strain-gauge'lerin yerleri sabitlenmiştir. Açılan kanal boşlukları epoksi esasl, çift bileşenli metal dolgu malzemesi ile doldurularak kapatılmış, dolgu malzemesinin kuruması için 1 gün beklenilmiştir. BÖÇ'lere yerleştirilecek olan strain-gauge'ler bu işlemlerden sonra üzerleri ayrıca TML-SB bantla kapatılmıştır. Böylece, yük hücresinin monotonik hareketi sırasında dolgu malzemesinden etkilenmesinin önlenmesi amaçlanmaktadır. BÖÇ'ün çekirdek gerilme-şekildeğiştirme davranışını tam olarak anlayabilmek için uygulanan kanala strain-gauge yerleştirme işleminin başarılı olduğu 
görülmüştür. Üretilen çaprazlara strain-gauge'ler sürtünmesiz yüzey malzemesinden önce yerleştirilmiştir.

\subsection{Sürtünmesiz Yüzey ve Dolgu Malzemesi}

Çekirdek eleman akarak eksenel şekildeğiştirdiğinde yanal yerdeğiştirmesi dış tüp+dolgu malzemesi tarafından tutulurken, iki eleman arasındaki sürtünmesiz yüzey de eksenel kuvvetin dış tüpe aktarılmasını engellemektedir. Çalışmada tasarlanarak üretilen BÖÇ'lerin sürtünmesiz yüzey malzemesi için düşük sürtünme katsayısı ve yüksek aşınma direncine sahip bir malzeme olan ve kendiliğinden metal yüzeyine yapışan politetrafloroetilen (PTFE) bantlar ve kauçuklu gres yağ kullanılmıştır. PTFE'nin statik ve dinamik sürtünme katsayısı 0.04, çekme dayanımı 21 35MPa, eğilme modülü 500MPa, aşınma direnci $85 \mathrm{~g} / \mu \mathrm{m}$ 'dir. Dolgu malzemesi olarak çimento esaslı, yüksek dayanımlı, normal priz alan, rötresiz, büzüşmeyen, dökülebilir akıcı kıvamda yüksek dayanımlı tamir harcı (grout) (KösterVGM5) kullanılmıştır. Yoğunluğu $2.26 \mathrm{~g} / \mathrm{cm}^{3}$ olan dolgu malzemesi tek bileşenlidir ve yalnızca su ile karıştırılarak üretilmektedir. Ön hazırlık aşamasında dolgu malzemesinden 150mmx150mm küp kalıplara 6 adet numune alınmıştır. Alınan örneklerden 3’ü 7. günde, diğer 3'ü 28. günde kırılmıştır. 7 günlük basınç dayanımı ortalama $\left(f_{c}\right)_{7}=52 M P a, 28$ günlük basınç dayanımı ortalama $\left(f_{c}\right)_{28}=64 \mathrm{MPa}$ olarak bulunmuştur. Elastisite modülü $E_{c}=37 G P a, 28$ günlük eğilmede çekme dayanımı $f_{c t k}=8 M P a$, Poisson oranı ise $v=$ 0.35 'dir.

\subsection{Malzeme Deneyleri Sonuçları}

Kanallı çekme deneyi parçalarında akmanın başladığı noktaya kadar okumalar alınmış sonrasında şekildeğiştirme ölçerler hasar görmüştür. Malzeme deneylerinden elde edilen sonuçlar BÖÇ’ün tasarımında ve üretiminde kullanılan malzemenin seçimine yönelik önemli bilgiler içermektedir. S235JR (BRB-SC1, BRB-SC3 ve BRB-SC4) ve S355JR (BRB-SC2 ve BRB-SC5) malzemelerinin mekanik özellikleri Çizelge 1'de özetlenmiştir. Burada; $\varepsilon_{y}, \varepsilon_{u}$, $F_{y c}, F_{u}, E$ sırasıyla akma şekildeğiştirmesi, maksimum uzama, akma gerilmesi, çekme gerilmesi ve elastisite modülünü göstermektedir. Çelik diş tüpler için S355JR çelik malzemesinden $140 \times 140 \times 5$ kare tüp kesitli ve akma dayanımı $345 M P a$ olan dış tüpler kullanılmıştır. Karşılaştırmalı gerilme-şekildeğiştirme eğrileri Şekil 1'de verilmektedir.

Çizelge 1 - Malzemelerin Mekanik Özellikleri

\begin{tabular}{llccccc}
\hline Numuneler & $\begin{array}{l}\text { Malzeme } \\
\text { Özelliği }\end{array}$ & $\begin{array}{c}\varepsilon_{y} \\
(\%)\end{array}$ & $\begin{array}{c}\varepsilon_{u} \\
(\%)\end{array}$ & $\begin{array}{c}F_{y c} \\
(M P a)\end{array}$ & $\begin{array}{c}F_{u} \\
(M P a)\end{array}$ & $\begin{array}{c}E \\
(G P a)\end{array}$ \\
\hline $\begin{array}{l}\text { BRB-SC1 } \\
\text { BRB-SC3 } \\
\text { BRB-SC4 }\end{array}$ & S235JR & 0.15 & 38.21 & 257 & 363 & 195 \\
\hline $\begin{array}{l}\text { BRB-SC2 } \\
\text { BRB-SC5 }\end{array}$ & S355JR & 0.19 & 25.45 & 373 & 543 & 204 \\
\hline
\end{tabular}




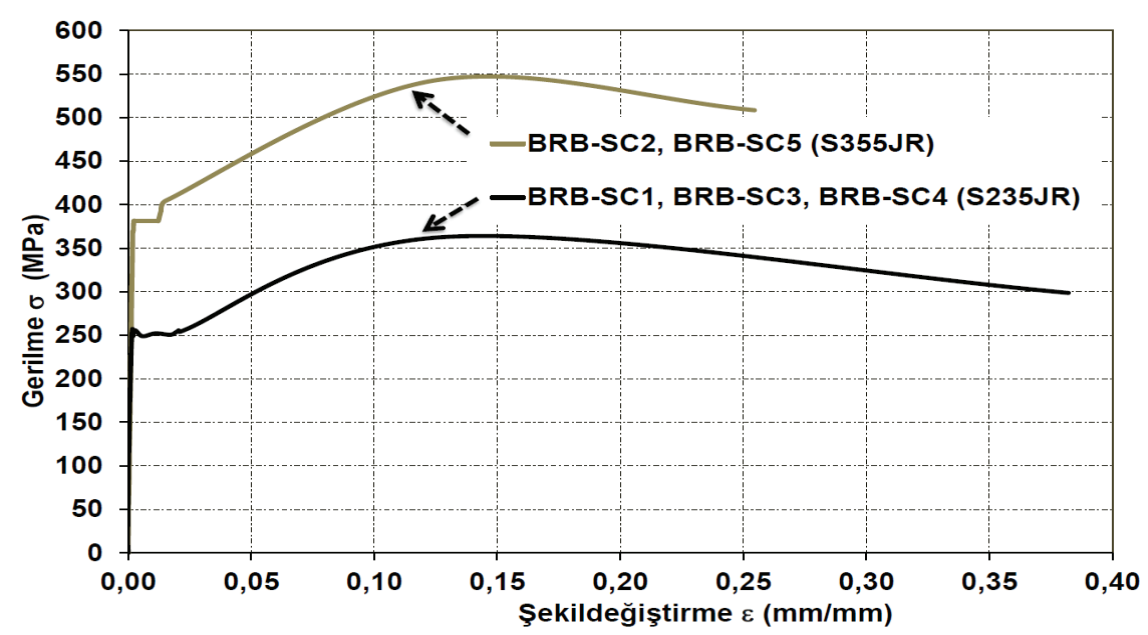

Şekil 1 - Çelik Malzemelerin Gerilme-Şekildeğiștirme Ĕgrileri

$\mathrm{Bu}$ eğrilerden en yüksek dayanımın S355JR'ye, en sünek davranışın S235JR'ye ilişkin olduğu anlaşıılmaktadır. BÖÇ çekirdeklerinde kullanılan çelik levhalardan kupon (malzeme) deneyleri için örnekler alınmış ve Şekil 1'deki eğriler elde edilmiştir. Özetle, Şekil 1'de verilen eğriler üretilen BÖÇ’lerin çekirdeklerinde kullanılan çelik levhaların kalınlıkları içindir. Kanallı deney parçalarında kesitin diğer yüzüne yapıştırılan strain-gauge okumaları ile de karşılaştırmalı olarak grafikler elde edilmiştir. Deney parçalarında akmanın başladığ 1 noktaya kadar okumalar alınmış, sonrasında şekildeğiştirme ölçerler hasar görmüştür. Ancak, bu uygulamanın BÖÇ'ün gerçek davranışını anlamada amaca yeterli derecede uygunluğu yapılan deneysel çalışmalarda kanıtlanmıştır. Çekme deneylerinden elde edilen sonuçlar birlikte değerlendirildiğinde, çelik BÖÇ’lerin üretimi için kullanılacak malzemelerin istenilen amaca ulaşmak için yeterli olduğu anlaşılmış, bu doğrultuda büyük numunelerin üretimi gerçekleştirilmiştir.

\section{BÖÇ TASARIMI, ÜRETIMİ VE DENEYLER}

\subsection{Numunelerin Tasarımı ve Üretimi}

Numunelerden BRB-SC1, BRB-SC2 ve BRB-SC3 ön çalışmalar kapsamında, BRB-SC4 ve BRB-SC5 ise esas/ana çalışmalar kapsamında tasarlanan, üretilen ve denenen numunelerdir. Şekil 2'de tasarlanarak denenen numunelerin deney düzeneğindeki genel görünüşleri görülmektedir. Numuneler hidrolik actuatorün/verenin kapasitesini aşmayacak şekilde tasarlanmıştır. Numunelerin boyutlandırılmasında AISC 341-10 [17] ve AISC-LRFD [18] yönetmelikleri esas alınmıştır. Uygulamada sıkça kullanılan dikdörtgen çekirdekli ve içi harçla dolgulu kare dış tüp şeklindeki BÖÇ’lerin tercih edilmesi parametre sayısını azaltmaktadır. Ayrıca akma bölgesi uzunluğunu maksimum yapan ve daha az yatay yük ile daha çok eksenel kuvvet oluşmasına neden olan diyagonal deney sistemi kullanılmışıtır. Numuneler $P_{y c}$ eksenel akma dayanımları ve $L(2275 \mathrm{~mm})$ çapraz toplam uzunlukları aynı olacak şekilde tasarlanmıştır. Böyle bir seçim numunelerin enerji yutma kapasitelerini 
karşılaştırırken kolaylık sağlamıştır. Çapraz sistem uzunluğu 3339mm'dir. Tüm numunelerin çekirdek akma bölgesi dikdörtgen enkesitlidir. Çekirdeğin tutulu olmayan uzunluğunda yerel burkulmaların oluşmaması için güçlendirme bölgesi haçvari enkesitli olarak tasarlanmıştır. $L_{1}$ BÖÇ'lerin mafsal noktaları arasındaki uzunluğu olup tasarlanan BÖÇ'ler de $2110 \mathrm{~mm}$ 'dir. Çalışmada, maksimum akma bölgesi uzunluğu $L_{y c} \leq 1410 \mathrm{~mm}$ olarak alınmıştır $\left(0.67 L_{1}\right)$.

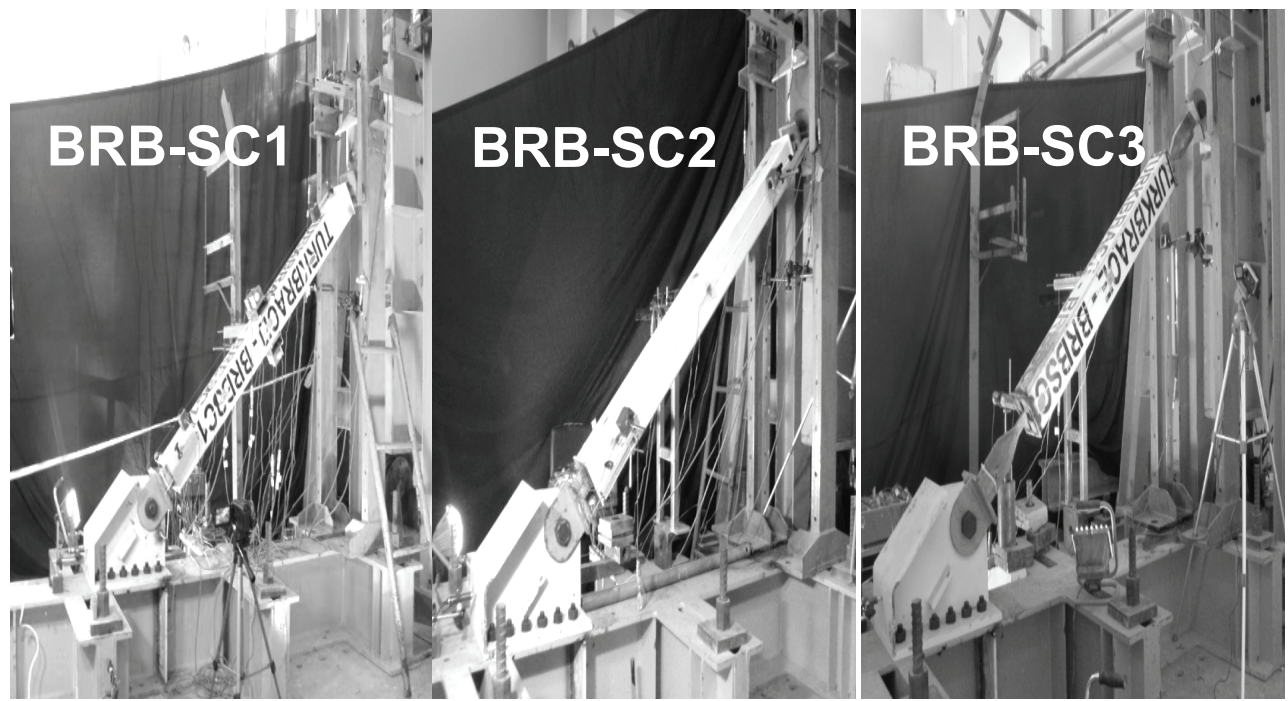

(a)

(b)

(c)

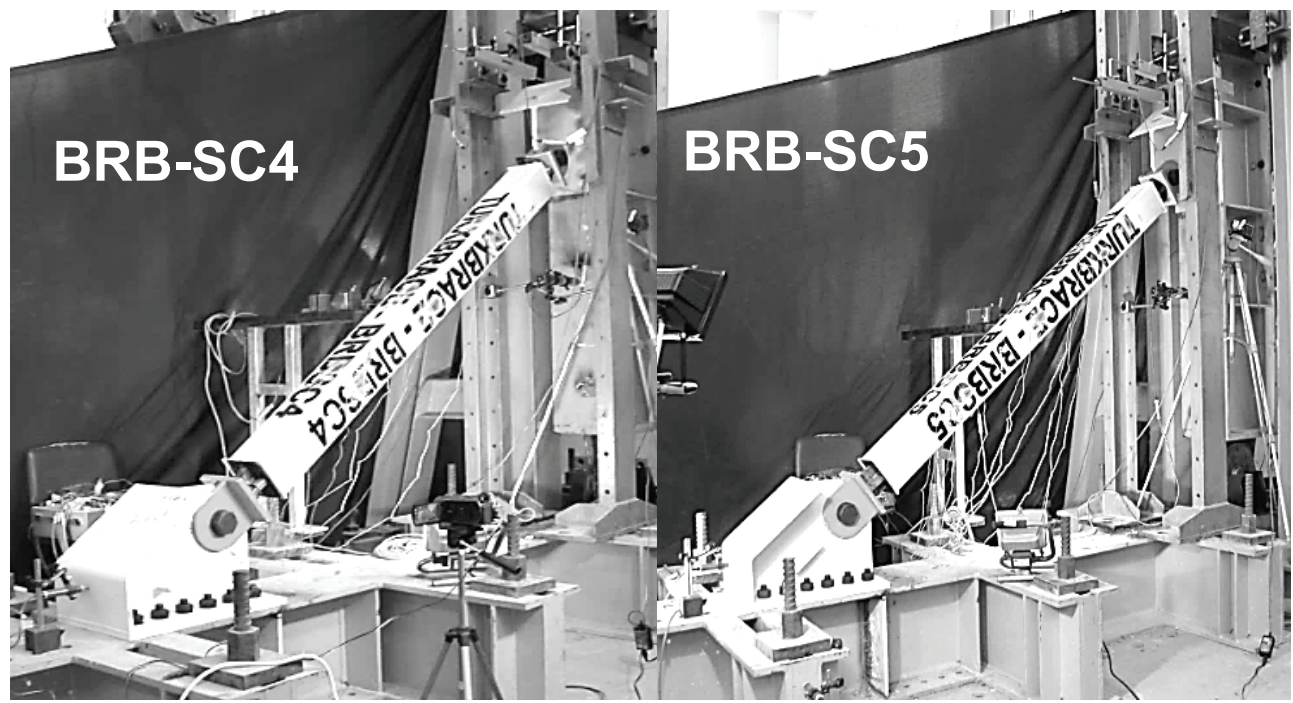

(d)

(e)

Şekil 2 - Numunelere Ilișkin Genel Görünüșler:

(a): $B R B-S C 1,(\boldsymbol{b}): B R B-S C 2,(\boldsymbol{c}): B R B-S C 3,(\boldsymbol{d}): B R B-S C 4,(\boldsymbol{e}): B R B-S C 5$ 
BÖÇ’ün burkulma dayanımı malzeme özelliklerinden sonra tahmin edilen etkin burkulma boyu katsayısı K'ya bağlıdır. Çaprazların burkulma dayanımlarının hesaplanmasında, düzlem dışı ve düzlem içi etkin burkulma boyu katsayıları, uç mesnet koşullarının mafsallımafsallı varsayımı ile $\mathrm{K}=1$ olarak alınmıştır. $\mathrm{KL}$ etkin burkulma boyu için $\mathrm{L}_{1}$ dikkate alınmıştır. Burkulmayı önleyen ortam (dolgu malzemesi+dış tüp) geometrik olarak her iki eksen etrafında eşit atalet momenti sağlayacak şekilde tasarlanmıştır. Ön çalışmalarda kullanılan numunelerde öncelikli olarak farklı uç detayları incelenmiştir. İç ve dış boşluk oluşturulması ve sürtünmesiz yüzey işlevinin arttırılmasına yönelik farklı detaylar ve malzemeler kullanılmıştır. Çekirdek güçlendirme bölgesinin oluşturulmasında, berkitme plakalarının çekirdek üzerinde doğru yere kaynaklanarak kümülatif enerji sönümleme miktarının arttırılmasına yönelik incelemelerde bulunulmuştur. Ön çalışmalar kapsamında üretilen 3 adet BÖÇ, sonrasında tasarlanan ve çalışmada esas olan 2 yeni BÖÇ’ün üretim kolaylığına, işlevselliğine, enerji sönümleme kapasitelerinin arttırılmasına yönelik teknolojik bilgi edinimlerine altyapı oluşturmuştur. Tasarlanan, üretilen ve denenen 5 numunenin genel özellikleri aşağıda verilmiştir:

- BRB-SC1: Sürtünmesiz yüzey malzemesi olarak tek kat PTFE bant kullanılmıştır. Normal akma dayanımlı (S235JR) çelik çekirdekli ve 355JR kalitesinde dış tüplü numunenin akma bölgesi uzunluğu $1410 \mathrm{~mm}(0.62 \mathrm{~L})$ 'dir.

- BRB-SC2: Sürtünmesiz yüzey malzemesi olarak burkulmayi önleyen ortam boyunca 3 kat PTFE ve üzerine kauçuklu gres yağı uygulanmıştır. Yüksek akma dayanımlı (S355JR) çelik çekirdekli ve S355JR kalitesinde çelik diş tüplü olarak tasarlanan numunenin akma bölgesi uzunluğu $1380 \mathrm{~mm}(0.61 \mathrm{~L})$ 'dir.

- BRB-SC3: BRB-SC1 numunesi ile aynı malzeme ve kesit özelliklerine sahip numunenin güçlendirilmiş uç kesiti burkulmayı önleyen ortam dışında bırakılarak farklı bir uç tasarımı denenmiştir. Sürtünmesiz yüzey malzemesi olarak 2 kat halinde PTFE uygulanmıştır. Akma bölgesi uzunluğu $1270 \mathrm{~mm}(0.56 \mathrm{~L})$ 'dir.

- BRB-SC4: Esas çalışma kapsamında olan numunenin sürtünmesiz yüzey malzemesi için 3 kat PTFE ve üzerine kauçuklu gres yağı uygulanmıştır. Kauçuklu gres yağı sürtünmesizliğe olan katkısının yanında suya ve dolayısıyla korozyona dayanıklı olması nedeniyle de tercih edilmiştir. Çekirdek S235JR kalitesinde ve $16 \mathrm{~mm} \times 30 \mathrm{~mm}$ enkesit boyutlarında akma bölgesi olan çelik plakadan hazırlanmıştır; akma bölgesi uzunluğu $1410 \mathrm{~mm}(0.62 \mathrm{~L})$ 'dir. Güçlendirme bölgesi berkitme plakalarının uç kaynaklanma noktası geçiş bölgesinden uzakta gerçekleştirilmiş ve kaynaklar köşede dönülmemiştir.

- BRB-SC5: Esas çalışma kapsamındaki diğer numune için BRB-SC4 numunesi ile aynı özelliklerde sürtünmesiz yüzey oluşturulmuştur. Güçlendirme bölgesinin hazırlanmasında kaynak noktasının doğru seçimi BRB-SC2 numunesinden elde edilen bulgular doğrultusunda iyileştirilmiştir. S355JR yüksek dayanımlı çelikten üretilmiş olup $12 \mathrm{~mm} \times 25 \mathrm{~mm}$ enkesitlidir; akma bölgesi uzunluğu $1380 \mathrm{~mm}(0.61 \mathrm{~L})^{\prime}$ dir.

Tasarlanan numunelerin genel plan ve kesit görünüşleri Şekil 3 'te verilmektedir. Çizelge 2 'de incelenen numunelerin çekirdek elemanlarının geometrik bilgileri vardır. Burada akma bölgesi uzunluğu ve genişliği $L_{y c}$ ve $b_{y c}$, güçlendirme bölgesi uzunluğu ve genişliği $L_{t r}$ ve $b_{t r}$, birleşim bölgesi uzunluğu ve genişliği $L_{c o n}$ ve $b_{c o n}$ ile gösterilmiştir; $t$ numunelerin çekirdek kalınlığıdır. 


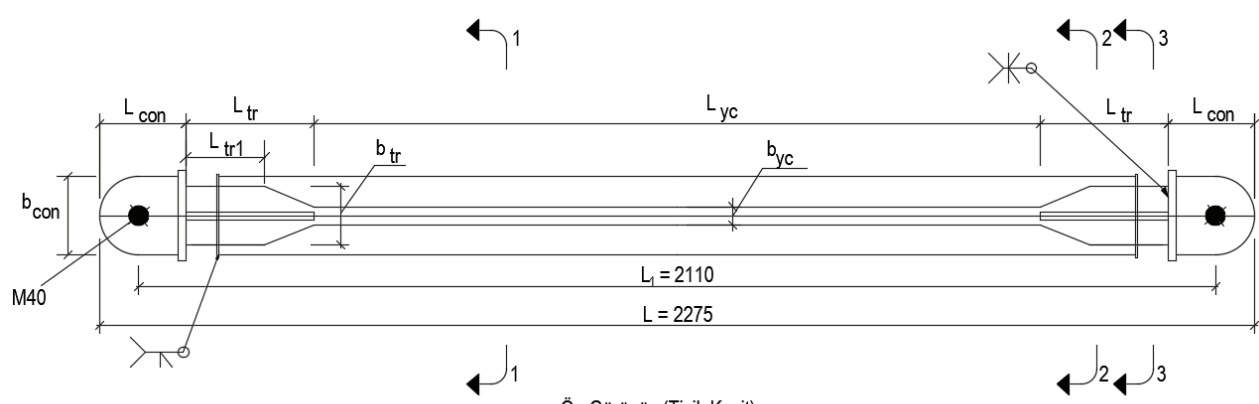

Ön Görünüş (Tipik Kesit)

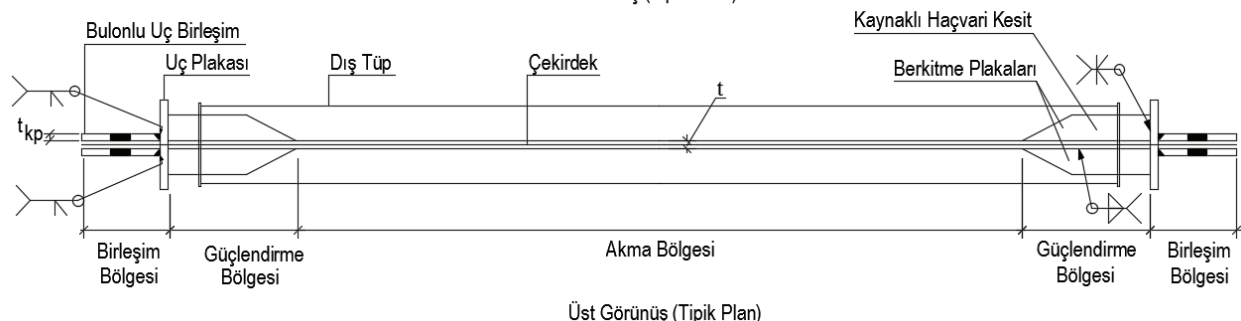

(a)

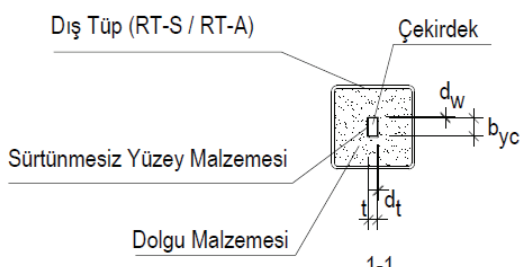

1-1

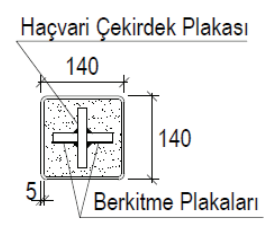

2-2

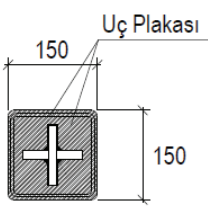

3-3

Kesitler

(b)

Şekil 3 - Numunelerin Geometrik Özellikleri, (a): Plan Görünüşleri, (b): Kesit Görünüsleri

Uçta bayrak plakalarına birleşimde 10.9 kalitesinde M40 yüksek dayanımlı bulonlar kullanılmıştır. Çelik BÖÇ’lerde kullanılan kaynak yöntemi gaz altı kaynağıdır (GMAW). Gaz altı kaynaklar üretimde Amerikan kaynak standartlarından (AWS) çelik için AWS D1.1/D1.1M'de [19] tanımlanan yöntemlerle yapılmıştır. Kaynak teli olarak E70 elektrodu kullanılmıştır. Bayrak plakaları deney düzeneğine bulonlanarak istenildiğinde sökülüp tekrar takılacak şekilde tasarlanmıştır. Yerel burkulma kapasitesini arttırmak için gövdelerine rijitleştirici plakalar kaynatılmıştır. Ayrıca plakaların düzlem dışı burkulmaları, serbest kenarlarından rijitleştiriciler kullanılarak kısıtlanmıştır. Kenar rijitleştiricilerin genişlikleri kiriş başlık genişliği ile eşit uzunluktadır. BÖÇ'lü çelik çerçevelerin, BÖÇ çekirdeğinin akmasına karşı gelen kuvvet düzeylerinde, akmadan kararlı olması için çaprazdan beklenilen maksimum kuvvetlere göre tasarlanması gerekmektedir. Bayrak plakaları S355JR yüksek dayanımlı çelik kalitesindedir. Bayrak plakalarından deney çerçevesine kesme kuvvetini aktaracak bulonlar sürtünme tipi olup 12 adet M24x75 (10.9) HSFG yüksek dayanımlı bulon özelliğindedir. Montaj sırasında bulonlara verilen tork değeri 1030Nm'dir. 
Çizelge 2 - Numunelerin Çekirdeklerinin Geometrik Özellikleri

\begin{tabular}{lccccc}
\hline Özellikler & BRB-SC1 & BRB-SC2 & BRB-SC3 & BRB-SC4 & BRB-SC5 \\
\hline$L_{y c}(\mathrm{~mm})$ & 1410 & 1380 & 1270 & 1410 & 1380 \\
$b_{y c}(\mathrm{~mm})$ & 30 & 25 & 30 & 30 & 25 \\
$t(\mathrm{~mm})$ & 16 & 12 & 16 & 16 & 12 \\
$L_{c o n}(\mathrm{~mm})$ & 185 & 184 & 185 & 185 & 184 \\
$b_{c o n}(\mathrm{~mm})$ & 165 & 165 & 165 & 165 & 165 \\
$L_{t r}(\mathrm{~mm})$ & 249 & 264 & 249 & 249 & 264 \\
$L_{t r 1}(\mathrm{~mm})$ & 160 & 172 & 160 & 160 & 172 \\
$b_{t r}(\mathrm{~mm})$ & 100 & 98 & 100 & 100 & 98 \\
\hline
\end{tabular}

\subsection{Deney Düzeneği ve Veri Toplama}

Deneysel çalışma için önceden klasik (burkulan) çaprazların deneylerinde kullanılmak üzere Haydaroğlu ve diğ. [20] tarafindan tasarlanan ve BÖÇ deneyleri için yeniden düzenlenen özel bir yükleme çerçevesi kullanılmıştır. Kullanılan deney düzeneği Şekil 4a'da görülmektedir. S275JR kalitesinde ve HE400A çelik profillerden üretilmiş olan yükleme çerçevesi çelik temel kirişine mafsallı bağlı kolon ve bu kolonun düzlem dışı hareketini engelleyen çift taraflı çelik payandalardan oluşmaktadır. Payandalar S275JR kalitesindeki HE200A profillerinden üretilmiştir. Kolon dibindeki mafsal E335 kalitesinde $70 \mathrm{~mm}$ çaplı pimden oluşmaktadır. $250 \mathrm{kN}$ itme-çekme ve $\pm 300 \mathrm{~mm}$ yerdeğiştirme kapasiteli, bilgisayar kontrollü MTS hidrolik veren (actuator) kullanılmıştır. Bütün taşıyıcı bileşenler ve birleşimler güvenlik faktörü en az 2.00 alınarak tasarlanmıştır. Çaprazların deney düzeneğine bağlantısı özel olarak tasarlanan bayrak plakaları ile yapılmış olup birleşimde 10.9 kalitesinde bulonlar kullanılmıştır. Deney düzeneğinin sistemin tümsel davranışına (dayanım ve rijitlik) olarak herhangi bir katkısı olmadığı bu çerçevede yapılan deneylerle kanıtlanmıştır. Bayrak plakaları deney düzeneği kolon/kiriş başlıklarına M24 (10.9) yüksek dayanımlı bulonlarla birleştirilmiştir. BÖÇ'ün ve yükleme çerçevesinin davranışını izlemek için uygun bir ölçüm düzeneği tasarlanmıştır. Kolon, kiriş ve bayrak plakalarının elastik kalıp kalmadığ 1 kritik noktalara yerleştirilen strain-gauge ve lineer yerdeğiştirme ölçerler (LVDT) ile kontrol edilmiştir. Numunelere ilişkin ölçüm düzeneği Şekil $4 \mathrm{~b}$ 'de görülmektedir. Her deneyde en fazla 16 adet strain-gauge kullanılmıştır. Strain-gauge'lerden ikisi alt ve üst bayrak plakası doğu ve batı yüzeylerine monte edilerek, bayrak plakalarının yüklemeler sırasında elastik kalıp kalmadığı kontrol edilmiştir. Dış tüpün davranışını izlemek amacıyla ise deneylerde her numunenin dış tüp temiz boyunun 1/4'üne ve bütün yüzeylere olmak üzere 12 adet strain-gauge yapıştırılmıştır. Kanal içerisindeki strain-gauge BRBKN olarak kodlanmıştır. 2 adet $300 \mathrm{~mm}$ kapasiteli LVDT (T1E ve T1W) yarı stroklu $( \pm 150 \mathrm{~mm})$ olarak hidrolik veren seviyesinde tepe yerdeğiştirmesini ölçmek için kullanılmıştır. Burkulmayı kontrol etmek amacıyla numunenin tam ortasında düzlem dışı yerdeğiştirmeyi ölçmek için yine $300 \mathrm{~mm}$ kapasiteli LVDT $(\mathrm{T} 5)$ yarı stroklu $( \pm 150 \mathrm{~mm})$ olarak kullanılmıştır. Diğer taraftan, 10 mm kapasiteli LVDT (T6) yarı stroklu olarak bayrak plakasında kullanılmıştır. Ayrıca, deney süresince deney düzeneğinin çalışmasının kontrol etmek için $100 \mathrm{~mm}, 10 \mathrm{~mm}$ 
ve $5 \mathrm{~mm}$ kapasiteli LVDT'lerden yararlanılmıştır. Deneyler sırasında elde edilen veriler için verileri çoğaltarak veri toplayııı üzerinden kontrol odasına aktaran kanal çoğaltma kutusu (AWS-50C Switch Box) kullanılmıştır. 10 kanallı veri toplayıcı (TML-TDS 302 Data Logger) ve buna bağlı Visual LOG TDS-7130 programı ile elde edilen elektriksel bilgi grafik ve text dosyası olarak kaydedilmiştir.

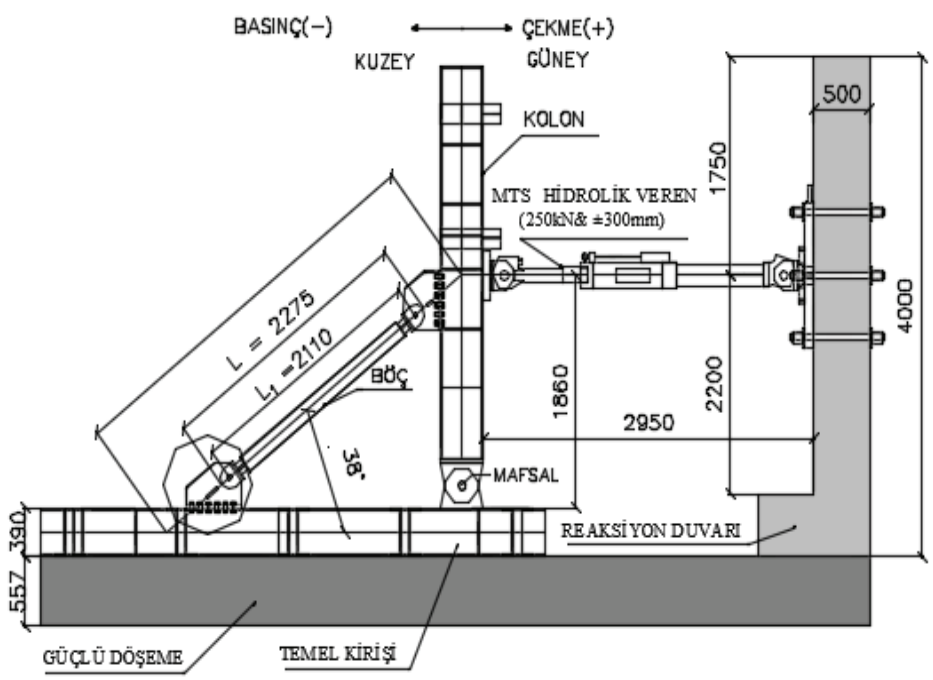

(a)

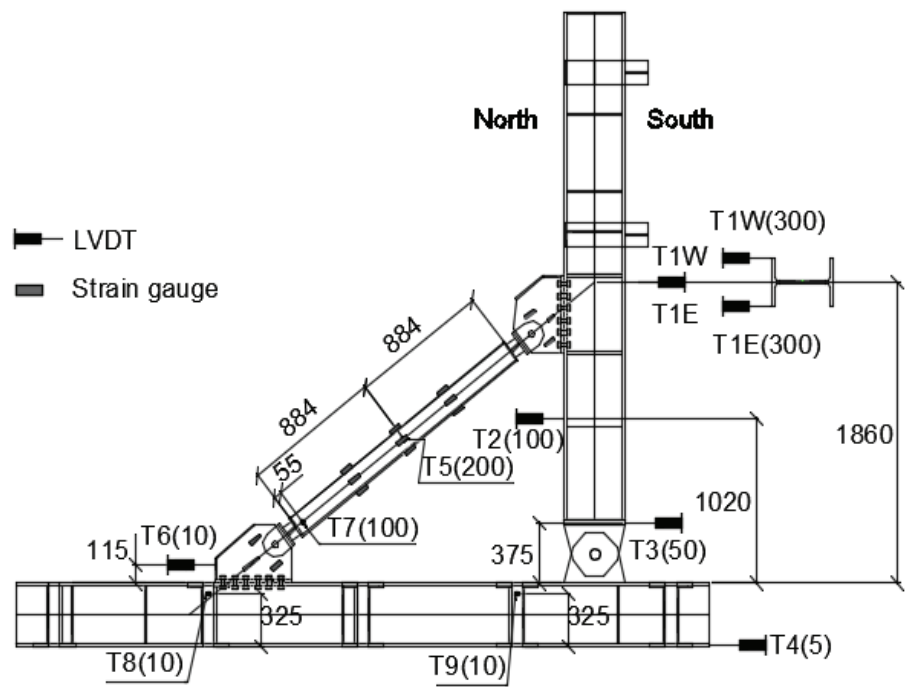

(b)

Şekil 4 - (a): Deney Düzeneğinin Genel Görünüşü, (b): Şekildeğiştirme ve Düzlem İçi Yerdeğiştirme Ölçerlerin Yerleşimi 


\subsection{Yükleme Protokolleri}

Deneyler AISC-341-10'da çelik çekirdekli BÖÇ’ler için verilen kriterlere uygun olarak ve yerdeğiştirme kontrollü gerçekleştirilmiştir. Numunelerin eksenlerindeki boy değişimiyle yakından ilişkili olan tepe yatay yerdeğiştirmesi kontrol parametresi olarak alınmıştır. Kupon deneylerinden elde edilen gerçek malzeme özellikleri kullanılarak SAP2000 [21] programı yardımıyla FEMA-356'da [22] verilen eksenel plastik mafsal özelliklerine göre itme (pushover) analizleri yapılarak numunelerin kuramsal kuvvet-yerdeğiştime eğrileri elde edilmiştir. Numunelerin öngörülen süneklik kapasiteleri, dayanım, akma ve göçme limitleri belirlenmiştir. AISC 341-10'da, BÖÇ’lü çerçeveli sistemin eksenel olmayan yükleme durumunda çaprazın tasarım kat ötelemesindeki yerdeğiştirme miktarı $\Delta_{b m}$ 'nin $5 \Delta_{b y}$ olarak alınabileceği önerilmektedir. Burada, $\Delta_{b y}$ çaprazın ilk akma noktasındaki yerdeğiştirme miktarıdır. Ayrıca $\Delta_{b m}$, kat yüksekliğinin \%1'inden az olmamalıdır. Akmadan önceki elastik bölgede $2 * \Delta_{b y} / 4,2 * 2 \Delta_{b y} / 4,2 * 3 \Delta_{b y} / 4$ genlikli yerdeğiştirme çevrimleri uygulanmıştır. AISC 341-10 ilkelerine göre numunelere uygulanan $4 * 1 \Delta_{b y}, 4 * 1.5 \Delta_{b y}, 4 * 2.5 \Delta_{b y}, 4 *$ $5 \Delta_{b y}, 4 * 7.5 \Delta_{b y}, 4 * 10 \Delta_{b y}$ yerdeğiştirme genlikli standart yükleme protokolü Şekil 5 'de verilmekte olup her numunenin göçme yerdeğiştirme seviyesi kesikli düşey çizgilerle belirtilmiştir. AISC 341-10 ilkelerine göre yükleme protokolü sonunda toplam plastik eksenel yerdeğiştirmesinin en az 200 $\Delta_{b y}$ olması gerektiği belirtilmektedir. Bu koşul eksenel yükleme deneylerinde zorunlu olmakla birlikte bu çalışmada olduğu gibi yapılan çerçeve tipine benzer deneylerde zorunlu tutulmamaktadır [14].

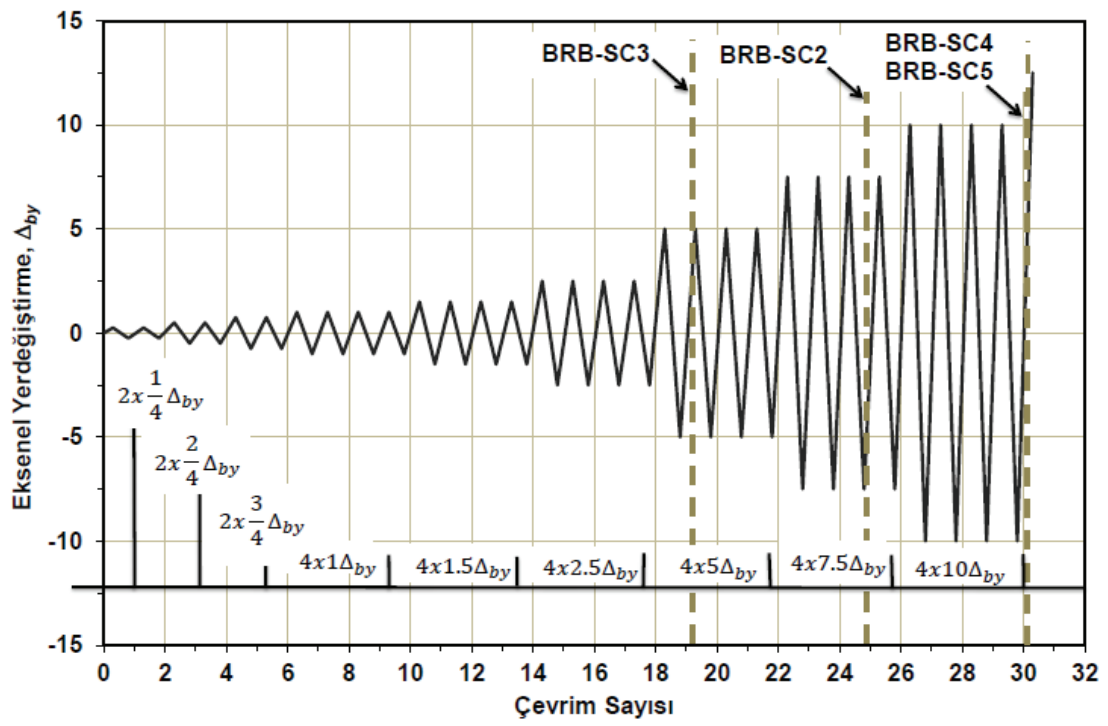

Şekil 5 - BRB-SC2, BRB-SC3, BRB-SC4 ve BRB-SC5 İçin Uygulanan Yükleme Protokolü

Simetrik olmayan yükleme protokollerinin davranış üzerine olan etkisini görmek amacıyla bir yakın fay yüklemesi de dikkate alınmış ve böylece BÖÇ’lerin yakın fay etkileri altında 
sınırlı olan deneysel çalışmalara bir katkı da sağlanmıştır [23]. Actuator kapasitesini aşmamak için basınçta sınırlı bir (\%0.65) yerdeğiştirme uygulanmasına karşın, çekmede protokol aynen (\%6) uygulanmıştır. Göreli öteleme oranlarına karşı gelen yerdeğiştirme değerleri hesaplanarak BRB-SC1 numunesi için yakın fay yükleme protokolü oluşturulmuştur. Hedeflenen ve actuator kapasitesini aşmamak için gerçekleştirilen yerdeğiştirme protokolleri Şekil 6'da işaretlenmiştir. Göreli öteleme oranlarından yerdeğiştirmelere geçişte deney düzeneği kiriş üst kotundan actuator merkez noktası arasındaki 1860mm'lik uzunluk alınmıştır.

\subsection{Deneysel Gözlemler}

Deney başlangıcında kuramsal akma ve kuvvet değerlerine göre deney kontrol edilmiştir. Elastik çevrimlerden sonra kuvvet-yerdeğiştirme grafiğinde gözle görülür bir akmanın oluşması ile deneysel akma yerdeğiştirmesi ve akma kuvveti belirlenmiştir. Eş zamanlı olarak metal yüzeyine yerleștirilen şekildeğiştirme ölçerin kupon deneyi ile elde edilen akma birim şekildeğiştirmesi değerinde olup olmadığ kontrol edilmiştir. İki kontrol parametresinden elde edilen sonuçların birbiriyle oldukça uyumlu olduğu görülmüştür. $\mathrm{Bu}$ durum, metal yüzeyinden akma yerdeğiştirmesi kontrolünün yapılması yönteminin etkinliğini kanıtlamakla birlikte yapılan kupon deneyleriyle elde edilen malzeme özelliklerinin doğruluğunu da göstermektedir. Numunelerin gerçek akma yerdeğiştirmesi belirlendikten sonra akma sonrası çevrimlerde, yükleme protokolü bulunan değere göre güncellenerek deneye devam edilmiştir. Numunelerin deneysel olarak elde edilen yatay kuvvet-yatay yerdeğiştirme histeretik eğrileri ile deney sonrası denenen tüm numunelerin ulaştıkları maksimum göreli öteleme oranlarına ilişkin alt uç/üst uç fotoğrafları ön çalışmalar (BRB-SC1, BRB-SC2 ve BRB-SC3) için Şekil 7'de, esas çalışmalar olan BRB-SC4 ve BRBSC5 numuneleri için Şekil 8'de verilmektedir.

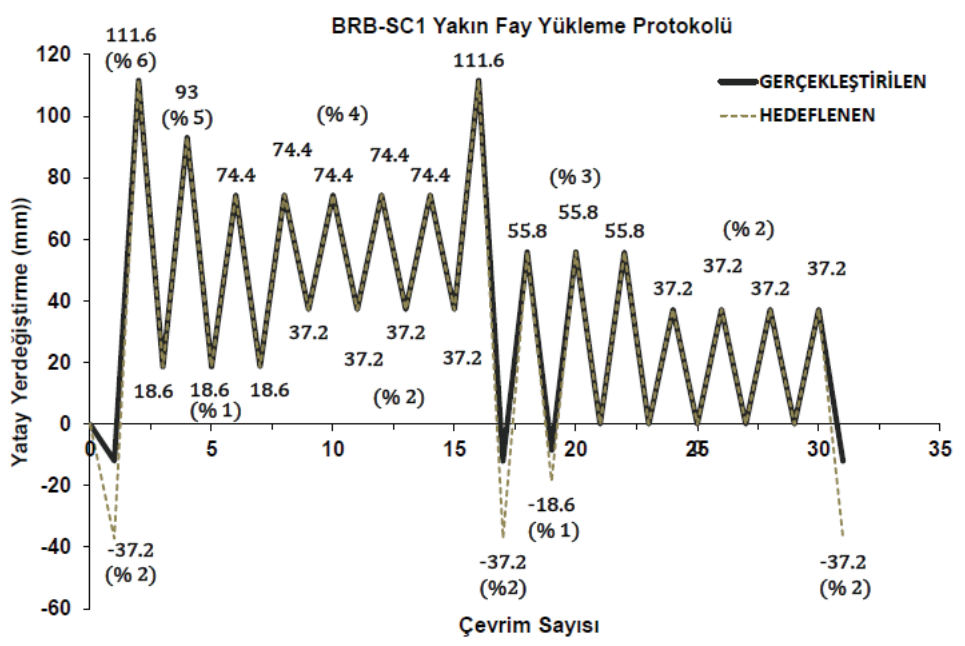

Şekil 6 - BRB-SC1 Numunesi İçin Yakın Fay Yükleme Protokolü 
Çelik Çekirdekli Burkulması Önlenmiş Çaprazların (BÖÇ) Tasarımı, Üretimi ve ...
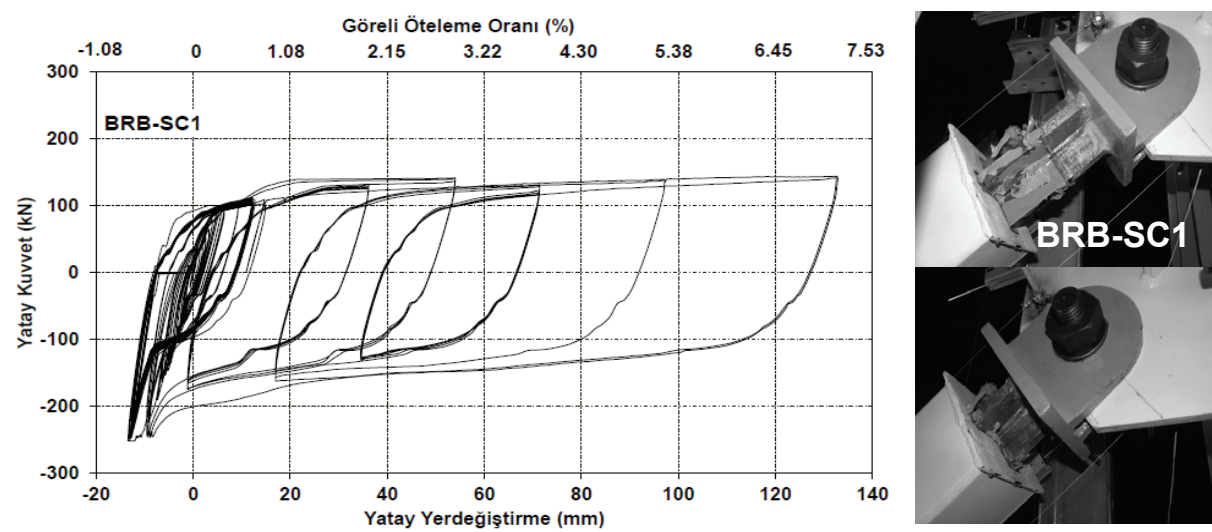

(a)
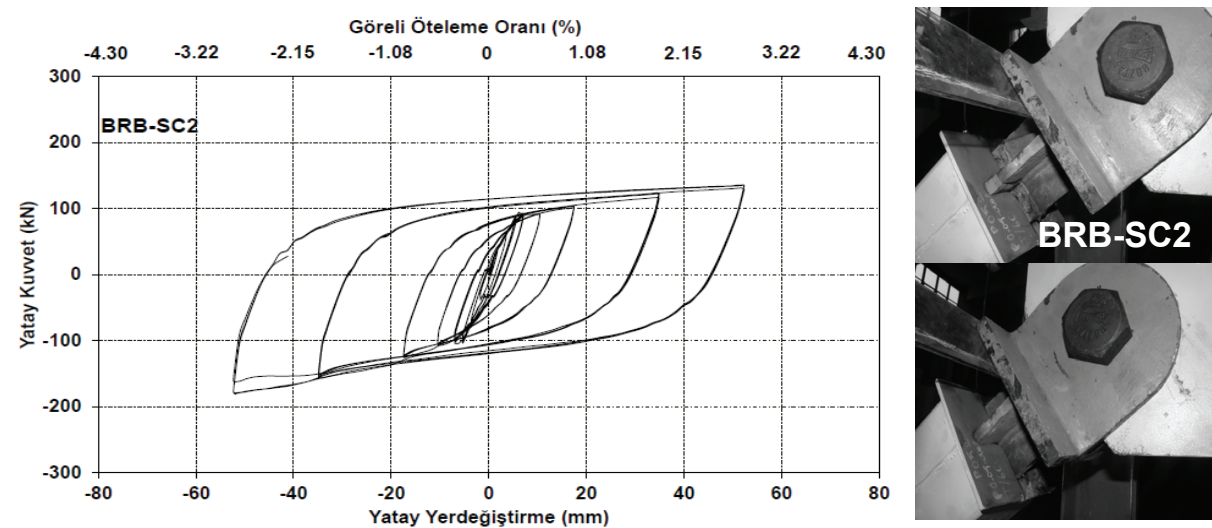

(b)
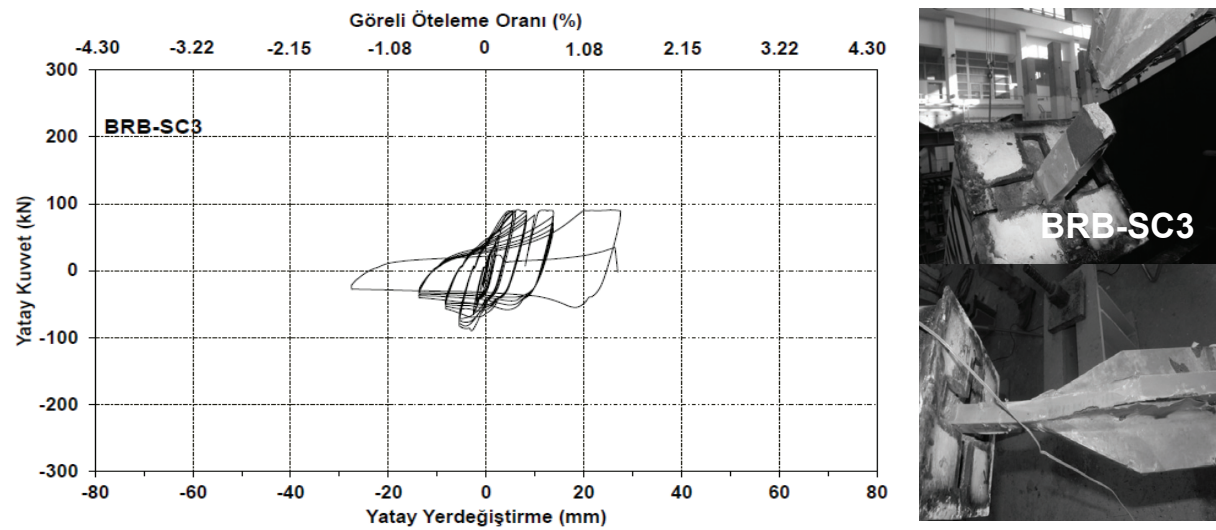

(c)

Şekil 7 - Ön Numunelere İlişkin Deneysel Histeretik Ĕ̆riler ve Deney Sonrası Ulaşılan Maksimum Çekme ve Basınç Piklerinde Uç Fotoğraflar:

(a): $B R B-S C 1,(\boldsymbol{b}): B R B-S C 2$, (c): $B R B-S C 3$ 

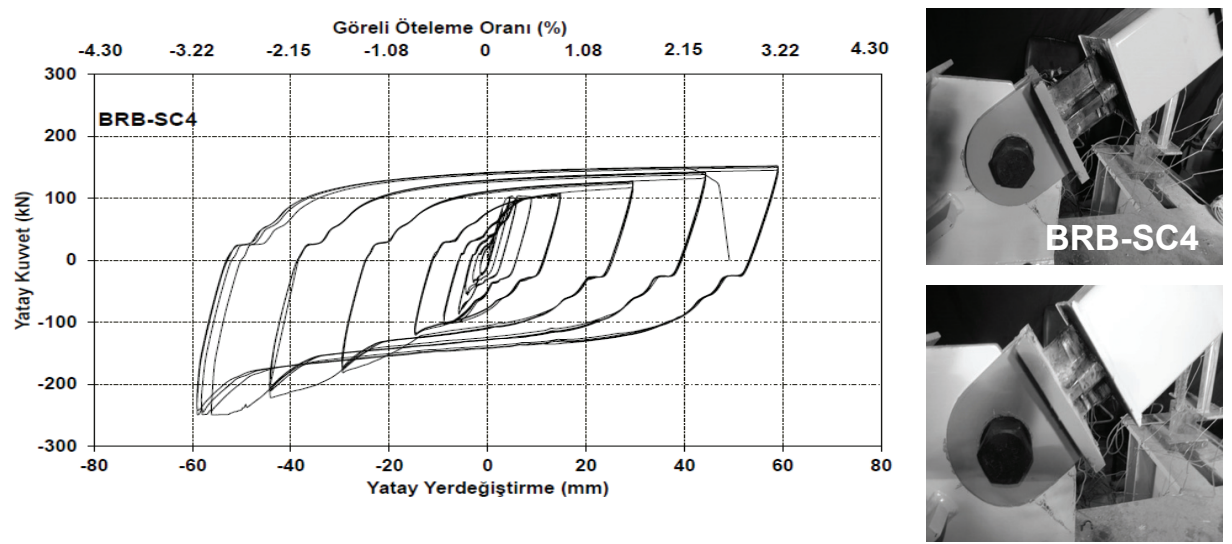

(a)
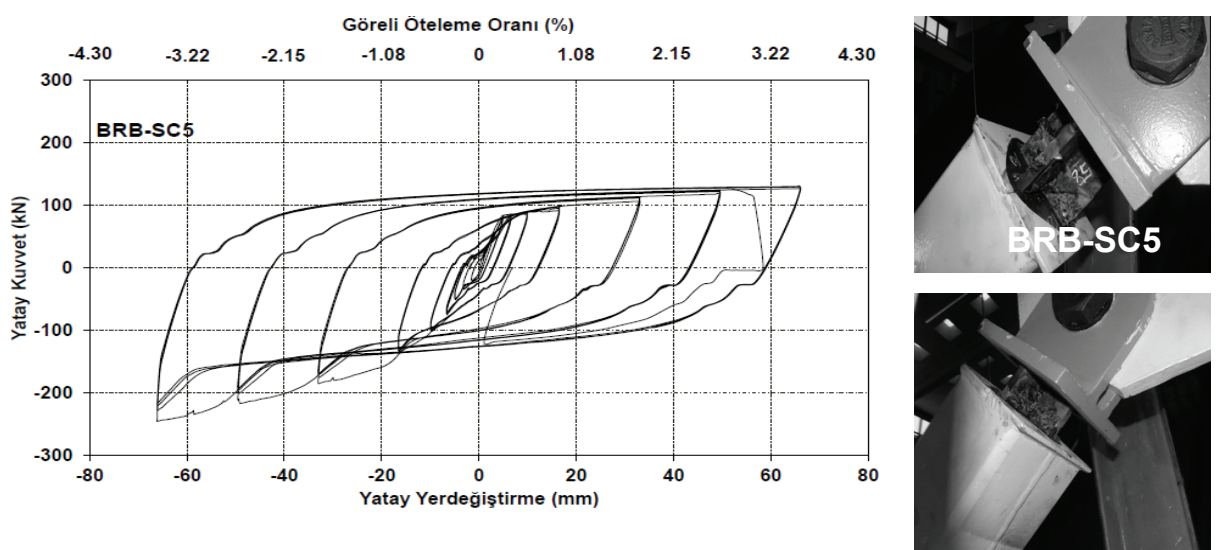

(b)

Şekil 8. Esas numunelere ilişkin deneysel histeretik ĕgriler ve deney sonrası ulaşılan maksimum çekme ve basınç piklerinde uç fotoğraflar: (a): BRB-SC4, (b): BRB-SC5

\section{5. Ön Çalışmalar (BRB-SC1, BRB-SC2, BRB-SC3)}

\subsubsection{BRB-SC1 Numunesi}

Ön çalışmalar için üretilen ilk çelik BÖÇ’tür. Numunenin statik itme analizi ile tahmin edilen akma yerdeğiştirmesi $\quad+5.41 \mathrm{~mm}$ 'dir. Çekme yüklemesinde $\Delta_{b y}=5.91 \mathrm{~mm}$ yerdeğiştirmesinde (\%0.32 göreli öteleme oranı) akma gözlenmiştir. Akma yerdeğiştirme seviyesinin ilk çekme pikinde $\mathrm{BRBKN}+1533 \mu$, T5 düzlem dişı yerdeğiştirme $+0.15 \mathrm{~mm}$ 'dir. İlk basınç pikinde BRBKN'nin $-1156 \mu$, T5'in $-0.12 \mathrm{~mm}$ olduğu görülmüştür. $\pm \Delta_{b y}$ seviyesinde maksimum çekme kuvveti $+98.62 k N$, maksimum basınç kuvveti ise $-165.90 k N$ 'dur. $\pm 2.5 \Delta_{b y}( \pm 14.78 \mathrm{~mm}$ yerdeğiştirme, $\% 0.79$ göreli öteleme oran1) seviyesinin ilk çekme pikinde maksimum kuvvet $+102.50 k N$, BRBKN $+4000 \mu$, basınç pikinde ise maksimum kuvvet $-248.00 \mathrm{kN}$ elde edilmiştir. Bu seviyenin ikinci çekme pikinde actuator kapasitenin basınç yüklemelerinde aşılacağı tahmin edilerek yükleme protokolü yeniden düzenlenmiştir. Düşük çevrimli/devirli yorulma yükleme protokolüne 
(Low Cycle Fatigue) göre öncelikle numunenin $\pm 2.03 \Delta_{b y}$ seviyesinde ve $\pm 12.00 \mathrm{~mm}$ yatay yerdeğiştirmede (\%0.65 göreli öteleme oranı) $\eta$ kümülatif plastik yerdeğiştirmesinin toplamda $200 \Delta_{b y}$ olmasını sağlayacak çevrim sayısı bulunmuştur. Sonuçta 96 çevrimin gerekli olduğu hesaplanmıştır. $\pm 12.00 \mathrm{~mm}$ yatay yerdeğiştirmede $\left( \pm 2.03 \Delta_{b y}\right)$ çekme kuvvetlerinin $+103.20 \mathrm{kN} \sim 112.30 \mathrm{kN}$, basınç kuvvetlerinin ise $-220.00 \mathrm{kN} \sim-248.99 \mathrm{kN}$ arasında değiştiği gözlenmiştir. BRBKN değerleri ise çekme yüklemelerinde $+4200 \mu \sim 5405 \mu$, basınç yüklemelerinde $-1250 \mu \sim 1400 \mu$ aralığındadır. 96. çevrimin sonunda elde edilen $\eta$ kümülatif plastik yerdeğiştirme $201.76 \Delta_{b y}$ 'dir. Numunede düşük çevrimli yorulma yükleme protokolü sonunda herhangi bir olumsuzluk gözlenmemiştir. BRB-SC1 numunesine düşük çevrimli yükleme sonrasında, yakın fay (near-fault) etkisini dikkate alan yükleme protokolü de uygulanmıştır [20]. BRB-SC1'in birleşimlerinde ve deney düzeneğinde herhangi bir olumsuzluk gözlenmemiştir. Yakın fay yükleme protokolü sonunda BRB-SC1 numunesinin $\eta$ kümülatif inelastik yerdeğiştirmesi toplamda $381.56 \Delta_{b y}$ 'dir. Uygulanan yükleme protokollerini geçen numunede kopma gerçekleşmemiştir.

\subsubsection{BRB-SC2 Numunesi}

BRB-SC2'nin statik itme analizi ile tahmin edilen çekme akma yerdeğiştirmesi $\pm 6.62 \mathrm{~mm}$ (\%0.36 göreli öteleme oranı)'dir. Numunede çekme yüklemesinde $\pm \Delta_{b y}$ için $+6.98 \mathrm{~mm}$ yerdeğiştirmesinde (\%0.38 göreli öteleme oranı) akma gerçekleşmiştir. Metal yüzeyine yerleştirilen BRBKN şekildeğiştirme ölçerinden ilk çekme pikinde $+2170 \mu$, basınç pikinde $-4800 \mu$ birim şekildeğiştirme okuması yapılmıştır. Akma yüklemesinin 2. çekme pikinde $+3350 \mu$, ikinci basınç pikinde $-5700 \mu$ değerine ulaşılmıştır. Bu değerler kupon deneylerinde elde edilen akma yerdeğiştirmesi birim şekildeğiştirme değerlerine yakındır. Akma yerdeğiştirmesinde, bayrak plakalarında, birleşimlerde, çaprazın genel durumunda herhangi bir olumsuzluk gözlenmemiştir. $\pm \Delta_{b y}$ seviyesinde elde edilen maksimum çekme kuvveti $+93.00 \mathrm{kN}$, maksimum basınç kuvveti $-105.00 \mathrm{kN}$ 'dur. Bu seviyede T5 düzlem dış1 yerdeğiştirmenin $-0.02 \mathrm{~mm} \sim-0.32 \mathrm{~mm}$ arasında değiştiği gözlenmiştir. $\pm 2.5 \Delta_{b y}$ seviyesinin ilk çekme pikine giderken $+99.57 \mathrm{kN}$ kuvvetine karşı gelen $+6881 \mu$ 'de BRBKN hasar görmüştür. $\beta$ basınç dayanımı düzeltme katsayısı 1.15 1.23 arasındadır. T5 düzlem dış1 yerdeğiştirme bu seviyenin son çekme pikinde $-0.42 \mathrm{~mm}$ olarak not edilmiştir. $\mathrm{Bu}$ seviyede bayrak plakalarında, birleşimlerde ve çaprazın genel stabilitesinde herhangi bir olumsuzluk gözlenmemiştir. $\pm 5 \Delta_{b y}( \pm 34.90 \mathrm{~mm}$ yerdeğiştirme, $\% 1.88$ göreli öteleme oranı) seviyesinde elde edilen maksimum çekme kuvveti $+123.00 \mathrm{kN}$, maksimum basınç kuvveti $-154.00 \mathrm{kN}$ 'dur. Bu seviyede $\beta$ basınç dayanımı düzeltme katsayısı 1.22 1.32 arasındadır. T5 düzlem dişı yerdeğiştirmesi seviyenin 2. çekme pikinde $-0.44 \mathrm{~mm}$ olarak ölçülmüştür. $\pm 7.5 \Delta_{b y}( \pm 52.35 \mathrm{~mm}$ yerdeğiştirme, $\% 2.82$ göreli öteleme oranı) seviyesinde elde edilen maksimum çekme kuvveti $+135.50 k N$, maksimum basınç kuvveti $-176.70 k N$ 'dur. $\beta$ basınç dayanımı düzeltme katsayısı 1.17 1.37 arasındadır. Numune $\pm 7.5 \Delta_{b y}$ ve $\% 2.82$ göreli öteleme oranı seviyesinde 4 . ve son çekme pikine giderken $-41.18 \mathrm{~mm}$ yerdeğiştirme ve $+28.03 k N$ 'da çekirdekten kopmuştur. Kopma sonrasında yapılan incelemelerde bayrak plakalarında, birleşim elemanlarında herhangi bir olumsuzluk gözlenmemiştir. Bu ikinci numunede maksimum basınç kuvvetinin, maksimum çekme kuvvetinden ortalama \%28 daha büyük olduğu belirlenmiştir. Deneysel $\omega$ çekme dayanımı düzeltme katsayısı ortalama olarak $1.47, \beta$ basınç dayanım düzeltme katsayısı ise 1.28 'dir. 


\subsubsection{BRB-SC3 Numunesi}

BRB-SC3 numunesinin statik itme analizi ile tahmin edilen akma yerdeğiştirmesi $+5.41 \mathrm{~mm}$ (\%0.29 göreli öteleme oranı)'dir. Numunede çekme yüklemesinde $\pm \Delta_{b y}$ için $+5.50 \mathrm{~mm}$ yerdeğiştirmede (\%0.30 göreli öteleme oranı) akma gözlenmiştir. Akma yerdeğiştirme seviyesinin ilk çekme pikinde BRBKN $+1119 \mu$, ilk basınç pikinde BRBKN $-950 \mu$ 'dir. $\pm \Delta_{b y}$ seviyesinde maksimum çekme kuvveti $+88.06 k N$, maksimum basınç kuvveti $-81.00 \mathrm{kN}$ 'dur. $\pm 5 \Delta_{b y}$ seviyesinde $( \pm 27.50 \mathrm{~mm}$ yerdeğiştirmede $\% 1.48$ göreli öteleme oranı) belirlenen ilk çekme pikine ilişkin kuvvet $+88.89 \mathrm{kN}$, ilk basınç pikindeki kuvvet $-27.50 k N$ 'dur. Numune yatay kuvvet- yatay yerdeğiştirme histeretik eğrisinde çekme kuvveti $+18.00 k N$ olduktan sonra $\pm 5 \Delta_{b y}$ seviyesinde 2 . basınç pikine giderken üst uçtan kopmuş ve deney sona ermiştir. Çaprazda çekirdeğin rijitleştirilmiş bölgeye geçişinde serbest bırakılan bölüm tüm davranışı olumsuz yönde etkilemiştir. Elastik çevrimlerde çekme ve basınç pikleri birbirine yakın değerler almasına karşın, inelastik çevrimlere girdikçe bu serbest uç bölümlerinde çekirdek kesitinin zayıf ekseni etrafında aşırı eğilmeler oluşmuş ve böylece basınç kuvvetlerinde düşüşler yaşanmıştır; ikinci mertebe etkilerinin artması ile BÖÇ davranışı klasik çapraz davranışına yakın bir duruma gelmiştir. Yine de burkulması önlenmemiş bir çaprazla karşılaştırıldığında önemli miktarlara ulaşan histeretik enerji elde edilmiştir. Bu durum, göreli olarak daha dolu olan histeretik eğriden de anlaşılmaktadır.

\subsection{Esas Çalışmalar}

\subsubsection{BRB-SC4 Numunesi}

Esas çalışmalar kapsamında önceki çaprazların olumsuzlukları giderildikten sonra üretilen BÖÇ'tür. BRB-SC4 numunesi tahmin edilen akma yerdeğiştirmesinin $\pm 1 / 4$ 'ündeki (\%0.07 göreli öteleme oranı) yatay yerdeğiştirmesi $\pm 1.35 \mathrm{~mm}$ olan 2 çevrimde, $\pm 2 / 4$ 'ündeki (\%0.15 göreli öteleme oran1) yatay yerdeğiştirmesi $\pm 2.71 \mathrm{~mm}$ olan 2 çevrimde, $\pm 3 / 4$ 'ündeki ( $\% 0.22$ göreli öteleme oranı) yatay yerdeğiştirmesi $\pm 4.08 \mathrm{~mm}$ olan 2 çevrimde elastik olarak davranmıştır. Elastik bölgede BRBKN şekildeğiştirmesi ilk çevrimde çekme etkisi altında $+1000 \mu$, basınç etkisinde $-455 \mu$, ikinci elastik çevrimde çekme etkisinde $+1000 \mu$, basınç etkisinde $-430 \mu$, üçüncü elastik çevrimde çekme etkisinde $+1300 \mu$, basınç etkisinde $-400 \mu$ değerleri elde edilmiştir. BRB-SC4'ün histeretik eğrisindeki gözle görülür akmanın oluştuğu nokta akma yerdeğiştirmesi olarak varsayılmıştır. BRBKN'nin erken hasar görerek okuma almamasının nedeni sonradan yapılan kesit açılımı ile anlaşılmıştır. Çekirdek, merkez noktadan koptuğundan, akma yerdeğiştirmesi piklerinde BRBKN öngörülenden erken hasar görmüştür; yapılan çekme deneylerinde de benzer bir durumla karşılaşılmıştır. BRB-SC4 numunesi statik itme analizi ile tahmin edilen akma yerdeğiştirmesi $+5.41 \mathrm{~mm}$ (\%0.29 göreli öteleme oranı)'dir. İlk çekme yüklemesinde tahmin edilen akma yerdeğiştirmesine çok yakın bir yerdeğiştirme değerinde akma gerçekleşmiştir. Numunede çekme yüklemesinde $\pm \Delta_{b y}$ için $+5.90 \mathrm{~mm}$ (\%0.32 göreli öteleme oranı) akma yerdeğiştirmesi olarak alınmıştır. Akma yerdeğiştirmesinde, bayrak plakalarında, birleşimlerde, çaprazın genel stabilitesinde herhangi bir olumsuzluk gözlenmemiştir. $\pm 1.5 \Delta_{b y}( \pm 8.85 \mathrm{~mm}$ yerdeğiştirme, \%0.48 göreli öteleme oranı) seviyesinde elde edilen maksimum çekme kuvveti $+102.00 \mathrm{kN}$, maksimum basınç kuvveti $-103.00 \mathrm{kN}$ 'dur. $\pm 2.5 \Delta_{b y}( \pm 14.75 \mathrm{~mm}$ yerdeğiştirme, \%0.79 göreli öteleme oranı) seviyesinde elde edilen 
maksimum çekme kuvveti $+107.00 k N$ ve basınç kuvvetleri sırasıyla $-120.00 k N$ olarak elde edilmiştir; bu düzeyde $\beta$ basınç dayanımı düzeltme katsayısı 1.12'dir. T5 düzlem dışı yerdeğiştirme ölçer bu seviyede batı doğrultusunda $-0.48 \mathrm{~mm}$ değerine ulaşmıştır. $\pm 5 \Delta_{b y}$ $( \pm 29.50 \mathrm{~mm}$ yerdeğiştirme, \%1.59 göreli öteleme oranı) seviyesinde maksimum çekme kuvveti $+128.00 \mathrm{kN}$ olup maksimum basınç kuvveti ise $-172.00 \mathrm{kN}$ 'dur; $\beta$ basınç dayanımı düzeltme katsayısı 1.34 olup basınç piklerinde basınç dayanımının artmaya başladığı gözlenmiş̧ir. $\pm 7.5 \Delta_{b y}( \pm 44.25 \mathrm{~mm}$ yerdeğiştirme, $\% 2.38$ göreli öteleme oranı) seviyesinde maksimum çekme kuvveti $+142.00 \mathrm{kN}$, maksimum basınç kuvveti $-203.00 \mathrm{kN}$ olarak elde edilmiş̧ir; $\beta$ değeri 1.43 'dür. $\pm 10 \Delta_{b y}( \pm 59.00 \mathrm{~mm}$ yerdeğiştirme, \%3.17 göreli öteleme oranı) seviyesinde maksimum çekme ve basınç kuvvetleri sırasıyla $+152.00 k N$ ve $-249.00 k N$ olarak tespit edilmiş olup $\beta$ değeri 1.64'e ulaşmıştır. Numune $\pm 12.5 \Delta_{b y}$ ve $\% 4.00$ öteleme oranı seviyesindeki ilk çekme pikine gidilirken $+50.14 \mathrm{~mm}$ yerdeğiştirme düzeyinde ve $+120.12 k N$ yatay yükte beklendiği üzere çekirdekten kopmuştur. Kopma sonrası çaprazın bayrak plakalarında herhangi bir olumsuzluk gözlenmemiştir. Bu da numunenin tasarlandığı şekliyle davranış gösterdiğini ortaya çıkarmaktadır. Deneysel çalışma sonucunda BRB-SC4'ün maksimum basınç kuvvetinin, maksimum çekme kuvvetinden ortalama $\% 65$ daha büyük olduğu belirlenmiştir; $\omega=1.47, \beta=1.65$ bulunmuştur.

\subsubsection{BRB-SC5 Numunesi}

BRB-SC5 numunesi tahmin edilen akma yerdeğiştirmesinin $\pm 1 / 4$ 'ündeki (\%0.09 göreli öteleme oranı) yatay yerdeğiştirmesi $\pm 1.65 \mathrm{~mm}$ olan 2 çevrimde, $\pm 2 / 4$ 'ündeki (\%0.18 göreli öteleme oranı) yatay yerdeğiştirmesi $\pm 3.29 \mathrm{~mm}$ olan 2 çevrimde, $\pm 3 / 4$ 'ündeki (\%0.27 göreli öteleme oranı) $\pm 4.94 \mathrm{~mm}$ olan 2 çevrimde elastik davranmıştır. Elastik bölgede ilk çevrimde çekme yüklemesi altında BRBKN $+1500 \mu$, basınç etkisinde $-740 \mu$, ikinci elastik çevrimde çekme yüklemesinde $+1588 \mu$, basınç yüklemesinde $-1000 \mu$, üçüncü elastik çevrimde çekme etkisinde $+1600 \mu$, basınç etkisinde $-1450 \mu$ değerleri okunmuştur. BRB-SC5'in statik itme analizi ile tahmin edilen çekme akma yerdeğiştirmesi $\pm 6.62 \mathrm{~mm}$ 'dir. Numunede çekme yüklemesinde $+\Delta_{b y}$ için $+6.61 \mathrm{~mm}$ yerdeğiştirmesinde (\%0.36 göreli öteleme oranı) akma gerçekleşmiştir. Akma sırasında metal yüzeyine yerleştirilen BRBKN şekildeğiştirme ölçerinden $+1923 \mu$, basınç yüklemesinde $-1021 \mu$ okumaları yapılmıştır. Akma yüklemesinin 2. çekme pikinde BRBKN $+2100 \mu$ değerinde okunmuştur. Bu değerler kupon deneylerinden elde edilen akma şekildeğiştirme değerlerine çok yakındır. Bu yolla, deneyde net bir şekilde akma yerdeğiştirmesi belirlenmiştir. Akma yerdeğiştirmesinde, bayrak plakalarında, birleşimlerde, çaprazın genel durumunda herhangi bir olumsuzluk gözlenmemiştir. $\pm \Delta_{b y}$ seviyesinde elde edilen maksimum çekme kuvveti $+87.00 \mathrm{kN}$, maksimum basınç kuvveti ise $-75.00 \mathrm{kN}$ 'dur. $\pm 1.5 \Delta_{b y}( \pm 9.92 \mathrm{~mm}$ yerdeğiştirme, $\% 0.53$ göreli öteleme oranı) seviyesinde elde edilen maksimum çekme kuvveti $+88.00 \mathrm{kN}$, maksimum basınç kuvveti ise $-99.50 \mathrm{kN}$ 'dur. Bu seviyede BRBKN'de çekme piklerinde $3500 \mu \sim 3680 \mu$ arasında değerler okunmuştur. $\pm 2.5 \Delta_{b y}( \pm 16.53 \mathrm{~mm}$ yerdeğiştirme, $\% 0.89$ göreli öteleme oranı) seviyesinde elde edilen maksimum çekme kuvveti $+99.00 k N$, maksimum basınç kuvveti ise $-132.00 k N$ 'dur. BRBKN okuması bu seviyenin ilk çekme pikine giderken $+3082 \mu$ 'de hasar görmüştür; $\beta 1.33$ değerine ulaşmıştır. $\pm 5 \Delta_{b y}( \pm 33.05 \mathrm{~mm}$ yerdeğiştirme, $\% 1.78$ göreli öteleme oranı) seviyesinde elde 
edilen maksimum çekme kuvveti $+111.00 k N$, maksimum basınç kuvveti ise $-165.00 k N$ 'dur; $\beta$ değeri 1.49 olarak elde edilmiştir. Bu seviyede basınç dayanımında göreli artış gözlenmiştir. $\pm 7.5 \Delta_{b y}( \pm 49.58 \mathrm{~mm}$ yerdeğiştirme, $\% 2.67$ göreli öteleme oranı) seviyesinde elde edilen maksimum çekme ve basınç kuvvetleri sirasıyla $+121.00 \mathrm{kN}$ ve $-189.00 k N$ 'dur; $\beta=1.56$ 'dır. $\pm 10 \Delta_{b y}$ ( $\pm 66.10 \mathrm{~mm}$ yerdeğiştirme, $\% 3.55$ göreli öteleme oranı) seviyesinde elde edilen maksimum çekme kuvveti $+130.00 \mathrm{kN}$, maksimum basınç kuvveti $-210.00 k N$ 'dur; $\beta$ değeri 1.62'ye ulaşmıştır. Numune $\pm 12.5 \Delta_{b y}$ ve $\% 4.44$ göreli öteleme oranı seviyesinde ilk çekme pikine gidilirken $+56.51 \mathrm{~mm}$ yerdeğiştirme ve $+112.53 k N$ 'da çekirdek bölgesinden kopmuştur. Kopma sonrası bayrak plakalarında herhangi bir olumsuzluk gözlenmemiştir. Deneysel çalışma sonucunda BRB-SC5'in maksimum basınç kuvvetinin, maksimum çekme kuvvetinden ortalama \%76 daha büyük olduğu bulunmuştur; sonuç olarak $\omega=1.46, \beta=1.76$ 'dır.

\section{DENEY SONUÇLARININ DEĞERLENDIRILMESI}

Ön numunelerden (BRB-SC1, BRB-SC2 ve BRB-SC3) elde edilen sonuçların sonraki numuneler için yol gösterici olduğu, pek çok çalışmada buna benzer öncü numunelerin kullanıldığı ve yukarıda detaylı olarak açıklanan davranış özellikleri nedeniyle önemli sonuçlar verdiği görülmüştür. $\mathrm{Bu}$ bölümde esas çalışmalar kapsamında olan çelik BÖÇ numunelerinin (BRB-SC4 ve BRB-SC5) daha başarılı olan deneylerinden elde edilen histeretik davranış özellikleri karşılaştırmalı olarak verilmiştir.

\subsection{Histeretik Davranışa İliş̧in Bulgular}

İncelenen numunelerin deneylerde yön değiştiren tekrarlı yükler altında yerdeğiştirme genlikleri $\left(\Delta_{b y}\right)$ ve yerdeğiştirmelere karşı gelen ortalama maksimum çekme $\left(T_{\max }\right)$ ve basınç kuvvetleri $\left(P_{\max }\right)$ ile standart yükleme protokolü sonucunda elde edilen $\omega$ çekme ve $\beta$ basınç dayanımı düzeltme katsayıları BRB-SC4 için Çizelge 3a'da, BRB-SC5 için Çizelge 3 'de özetlenmiştir. BRB-SC5 numunesinde, diğer numuneye göre daha büyük $\beta$ değerleri elde edilmiştir. Her iki numunede $\beta$ değerindeki artışların sürtünmesiz yüzey oluşturma tekniği ile ilgili olduğu, sonrasında yapılan kesit açlımlarında anlaşılmıştır. Histeretik eğrilerde basınç bölgesinde $\% 2$ göreli öteleme oranından sonraki değerlerde izlenen sivrileşmenin nedeni de budur. Numunelere ilişkin kümülatif enerji yutma kapasiteleri histeretik eğri altında kalan toplam alanın hesaplanmasıyla elde edilmekte olup Şekil 9'da karşılaştırmalı olarak verilmiştir. Numunelerin davranışını gösteren önemli parametrelerle birlikte deneysel iki doğrulu yatay kuvvet-yatay yerdeğiştirme eğrileri de elde edilmiş ve Şekil 10'da verilmiştir. Çalışma kapsamında incelenen BÖÇ'lerden en başarılı olanlarda azaltılmamış kesit bölgesinde göçme öncesi ulaşılan maksimum eksenel yerdeğiştirme değerleri de hesaplanmıştır. Bu değerler BRB-SC4 ve BRB-SC5'de sırasıyla \%3.17 ve \%3.60 olarak hesaplanmıştır. Literatürdeki benzer diğer BÖÇ’lerle karşılaştırıldığında, BRB-SC4 ve BRB-SC5'in göçme öncesinde göreli olarak yüksek şekildeğiştirme değerlerine ulaştığı görülmektedir.

Yön değiştiren tekrarlı yükler/yerdeğiştirmeler altında numunelerin sönümledikleri enerji miktarını ifade etmenin bir diğer yolu etkili sönüm oranın ( $\xi$ effb) hesaplanmasıdır. Bu değer 
özellikle deprem etkileri altındaki bu tür sistemlerin performansı bakımından önemlidir. Numunelerin enerji sönümleme miktarları uygulanan çevrim sayısı ile orantılıdır. BRB-SC4 numunesi normal akma dayanımlı (S235JR), BRB-SC5 numunesi yüksek akma dayanımlı (S355JR) çelik malzemesinden üretilmiştir. Şekil 9'dan görüleceği üzere BRB-SC4'ün enerji yutma kapasitesi ve kopma ömrü az da olsa BRB-SC5'den fazladır. Numunelerin $\eta$ kümülatif inelastik yerdeğiştime, $E_{h}$ enerji yutma miktarları, $\xi_{\text {effb }}$ etkili sönüm oranları ve maksimum göreli öteleme oranları hesaplanmış ve Çizelge 4 'de özetlenmiştir. Buradaki kümülatif inelastik yerdeğiştirme değerleri deney boyunca son çevrimlerden elde edilmiştir. Tüm çevrimler göz önünde bulundurulduğunda kümülatif inelastik yerdeğiştirmeler her iki numune için de $1360 \Delta_{\text {by }}$ olarak elde edilmiştir. Enerji yutma miktarları karşılaştırıldığında ise BRB-SC4/BRB-SC5 oran1 1.02'dir. En yüksek etkili sönüm oranı BRB-SC4 numunesinden ve \%39.89 olarak elde edilmiştir. Deney sırasında numunelerin kaynaklı birleşimlerinde, bayrak plakasına olan bulonlu birleşimlerinde herhangi bir olumsuzluk gözlenmemiştir. BÖÇ'lü çerçeve sistemlerde genelde sorun yaşanan bölgeler uç bayrak levhalarının olumsuz performanslarıdır. Bu çalışmada, bayrak plakalarının performansı yeterli görülmüştür.

Çizelge $3 a$ - BRB-SC4 Numunesi Davranış Özellikleri

\begin{tabular}{cccccc}
\hline$\Delta / \Delta_{b y}$ & $\begin{array}{c}\Delta_{b y} \\
(\mathrm{~mm})\end{array}$ & $\begin{array}{c}T_{\max } \\
(\mathrm{kN})\end{array}$ & $\begin{array}{c}P_{\max } \\
(\mathrm{kN})\end{array}$ & $\omega$ & $\beta$ \\
\hline $4 x 1.0 \Delta_{b y}$ & \pm 5.90 & 102.00 & -85.75 & 1.00 & 0.84 \\
$4 \times 1.5 \Delta_{b y}$ & \pm 8.85 & 101.75 & -102.75 & 1.00 & 1.01 \\
$4 \times 2.5 \Delta_{b y}$ & \pm 14.75 & 104.50 & -117.50 & 1.02 & 1.12 \\
$4 \times 5 \Delta_{b y}$ & \pm 29.50 & 123.75 & -172.00 & 1.21 & 1.39 \\
$4 x 7.5 \Delta_{b y}$ & \pm 44.25 & 138.25 & -203.00 & 1.37 & 1.47 \\
$4 \times 10 \Delta_{b y}$ & \pm 59.00 & 149.63 & -247.38 & 1.47 & 1.65 \\
\hline
\end{tabular}

Çizelge 3 - BRB-SC5 Numunesi Davranış Özellikleri

\begin{tabular}{cccccc}
\hline$\Delta / \Delta_{b y}$ & $\begin{array}{c}\Delta_{b y} \\
(\mathrm{~mm})\end{array}$ & $\begin{array}{c}T_{\max } \\
(\mathrm{kN})\end{array}$ & $\begin{array}{c}P_{\max } \\
(\mathrm{kN})\end{array}$ & $\omega$ & $\beta$ \\
\hline $4 \times 1.0 \Delta_{b y}$ & \pm 6.61 & 86.00 & -73.13 & 1.00 & 0.86 \\
$4 \times 1.5 \Delta_{b y}$ & \pm 9.92 & 87.13 & -98.78 & 1.01 & 1.13 \\
$4 \times 2.5 \Delta_{b y}$ & \pm 16.53 & 94.13 & -130.75 & 1.09 & 1.39 \\
$4 \times 5 \Delta_{b y}$ & \pm 33.05 & 109.88 & -165.00 & 1.28 & 1.50 \\
$4 \times 7.5 \Delta_{b y}$ & \pm 49.58 & 119.75 & -189.00 & 1.39 & 1.58 \\
$4 \times 10 \Delta_{b y}$ & \pm 66.10 & 127.50 & -225.00 & 1.48 & 1.76 \\
\hline
\end{tabular}




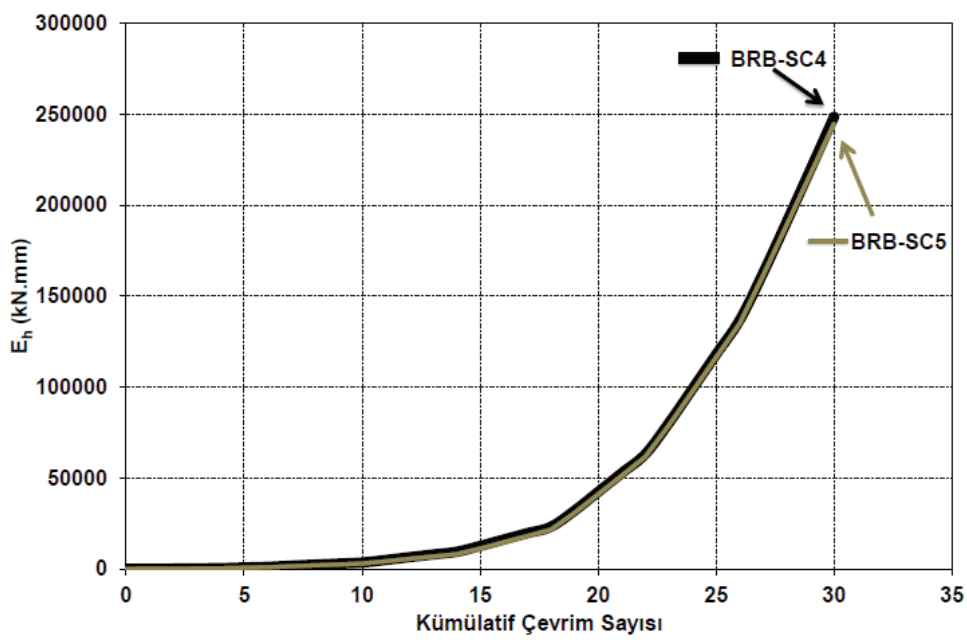

Şekil 9 - BRB-SC4 ve BRB-SC5 Numunelerinin Kümülatif Histeretik Enerji Eğrileri
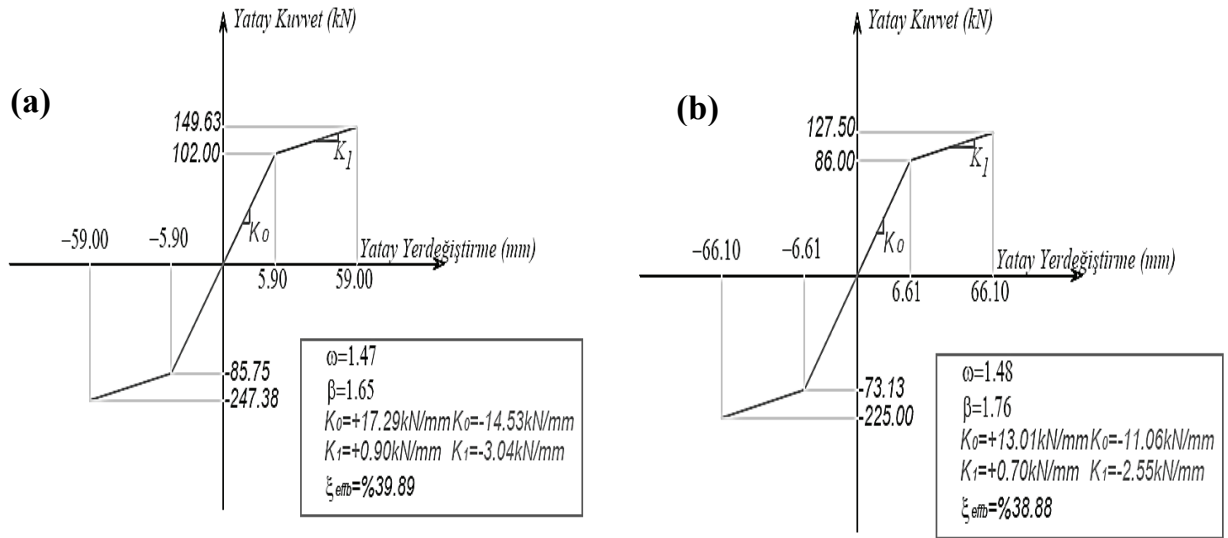

Şekil 10 - Numunelerin Deneysel İki Doğrulu Yatay Kuvvet-Yatay Yerdeğiştirme Ĕ̆rileri, (a): $B R B-S C 4$, (b): $B R B-S C 5$

Çizelge 4 - $\eta$ Kümülatif İnelastik Yerdeğiştirme, $E_{h}$ Enerji Yutma Miktarlarl, $\xi_{\text {effb }}$ Etkili sönüm ve maks. Göreli öteleme oranlarl.

\begin{tabular}{ccccc}
\hline Numuneler & $\eta$ & $\begin{array}{c}E_{h} \\
(\mathrm{kN.mm})\end{array}$ & $\begin{array}{c}\xi_{\text {effb }} \\
(\%)\end{array}$ & $\begin{array}{c}\text { Maks. göreli } \\
\text { öteleme oranı (\%) }\end{array}$ \\
\hline BRB-SC4 & $172 \Delta_{b y}$ & $248,507.90$ & 39.89 & 3.17 \\
BRB-SC5 & $172 \Delta_{b y}$ & $244,763.50$ & 38.88 & 3.55 \\
\hline
\end{tabular}




\section{OLUŞAN HASARIN VE GÖÇMENIN BELİRLENMESI}

Her numune deneyden sonra yarı boyu kesitinde açılarak oluşan hasarın ve göçme modunun belirlenmesi için gözlem ve incelemelerde bulunulmuştur. Kesit açılım fotoğrafları BRBSC4 numunesi için Şekil 11a'da, BRB-SC5 numunesi için Şekil 11b'de verilmiş̧ir. Kuramsal olarak tahmin edilen davranışla, deneysel davranışın uyum/uyumsuzluk durumu, deneysel gözlemlerin nedenleri yapılan kesit açılımları ile anlaşılmıştır. Numunelerde, yüksek dayanımlı dolgu harcında herhangi bir çatlak oluşumu gözlenmemiştir. Bu durum dolgu malzemesinin yük aktarmadı̆̆ını da kanıtlamaktadır. Genel olarak gözlemler ve bulgular aşağıda özetlenmiş̧tir:

- BRB-SC4 numunesi, beklenildiği üzere, çekirdek orta noktasından kopmuştur. İnelastik şekildeğiştirmeler strain-gauge civarında yoğunlaştığından ve kopma bu bölgede olduğundan metal yüzeyine yerleştirilen strain-gauge erken hasar görmüsşür. Numunenin çelik çekirdekte zayıf ekseni doğrultusunda çok modlu (dalgalı) burkulmaların olduğu görülmüş̧ür. Bu hasar ve göçme modu dışında, çekirdek bölgesinin ötesinde bir sorun görülmemiştir.

- BRB-SC5 numunesi çekirdek orta noktasına çok yakın bir noktadan kopmuştur. Benzer şekilde, çok modlu bir burkulma biçimi vardır. Yine çelik çekirdek dışında kalan uç bölgelerde herhangi bir sorun yaşanmamıştır.

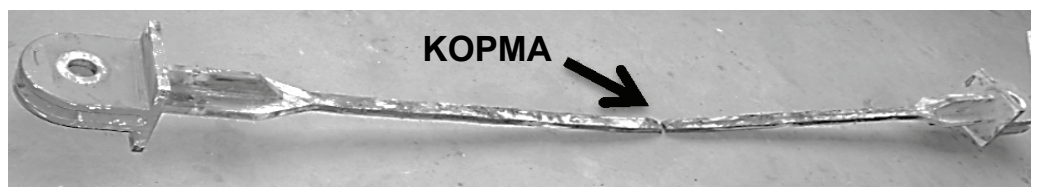

(a)

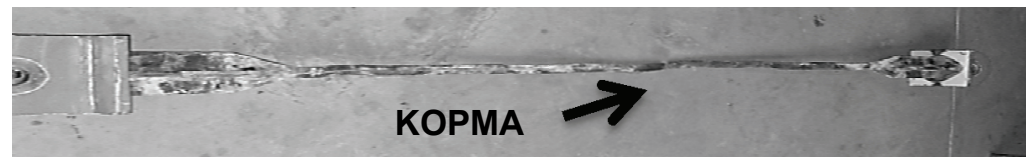

(b)

Şekil 11 - Numunelerin Kesit Açılım Fotoğraflar; (a): BRB-SC4, (b): BRB-SC5

\section{SONUÇLAR}

Türkiye'deki olanaklarla tasarlanarak üretimi gerçekleştirilen farklı kalitedeki çelik çekirdekli ve dış tüplü iki adet gerçeğe yakın boyutlardaki BÖÇ'ün, yön değiștiren tekrarlı yükler altındaki histeretik davranışı deneysel olarak incelenmiştir. Özellikle tasarım aşamasına detaylı olarak değinilmiş, malzeme araştırması, malzeme deneyleri kapsamlı biçimde açıklanmıştır. Çalışmada aynı akma daynımlı, basit uç detaylarına sahip 5 çelik çekirdekli ve çelik dış tüplü BÖÇ ele alınmıştır. Birinci grup BÖÇ serisi ön çalışmalar başlığ 1 altında değerlendirilmiş olup 3 BÖÇ’ten (BRB-SC1, BRB-SC2 ve BRB-SC3) oluşmuştur. Çalışmadaki deneysel bulgular ağırlıklı olarak esas çalımalar kapsamında değerlendirilen 2 
BÖÇ’ten (BRB-SC4 ve BRB-SC5) elde edilen sonuçlardır. Bu deneysel çalışmadan elde edilen başlıca sonuçlar aşağıda sıralanmıştır:

- Üretilen BÖÇ’lerde pek çok önceki deneysel çalışmalarda karşılaşılan ve en büyük sorun olan herhangi bir tümsel burkulma sorunu gözlenmemiştir. Bayrak plakaları, kolon ve kiriş şekildeğiştirme okumaları deney düzeneğinin deney boyunca elastik kaldığını göstermektedir. Bayrak plakalarının elastik davranışı, akmanın yalnızca çekirdek akma bölgesi uzunluğu boyunca oluştuğunu, çekirdek güçlendirme ve birleşim bölgelerinin elastik kaldığını ortaya koymaktadır.

- $\quad$ BRB-SC4 numunesi $\pm \% 3.17\left(10 \Delta_{b y}\right)$, BRB-SC5 numunesi ise $\pm \% 3.55\left(10 \Delta_{b y}\right)$ göreli öteleme oranında göçmüştür. En yüksek $\beta$ ve $\omega$ katsayıları BRB-SC5 numunesinde elde edilmiş olup sırasıyla 1.76 ve 1.48 'dir. Her iki numunede de göçmeye yakın yüksek öteleme oranlarında $\beta>1.3$ elde edilmiştir. $\beta$ katsayısını arttıran faktörlerin başında sürtünmesiz yüzey oluşturma kusur ve eksiklikleri ile iç boşluk verme şekli olduğu düşünülmektedir.

- Deney boyunca son çevrimlerden elde edilen $\eta$ kümülatif inelastik yerdeğiştirmeler her iki numunede de $172 \Delta_{b y}$ olarak elde edilmiştir. Tüm çevrimler göz önünde bulundurulduğunda ise kümülatif inelastik yerdeğiştirme değeri her iki numune için $1360 \Delta_{b y}$ 'dir.

- Numunelerde elde edilen etkili sönüm oranlarının büyük değeri \%39.89 ile BRB-SC4 numunesine aittir.

- BÖÇ’lerin çekirdek üzerinden şekildeğiştirme ölçümlerinin yapılması için metal yüzeyine açılan kanallara strain-gauge yerleştirilmiştir. $\mathrm{Bu}$ uygulama bilindiği ve ulaşıldığı kadarıyla BÖÇ teknolojisi için yeni bir uygulama olmuştur. BÖÇ'lerin deneyde akma yerdeğiştirmesinin net bir şekilde belirlenmesi bu yöntemle gerçekleştirilmiştir.

- Ön çalışmalar kapsamındaki numunelerde akma bölgesinden çekme bölgesine geçişte kullanılan berkitme plakalarının kaynak uç noktası numunelerde kesitin genişlediği noktaya çekilmiştir. kaynak köşelerinin dönülmesi kesitin en dar olduğu yerden isıdan etkilenen bölge (HAZ) nedeniyle çekirdeğin kopmasına yol açmıştır. Ön çalışmalarda görülen bu olumsuzluk esas çalışmalar kapsamındaki BÖÇ’lerin üretiminde dikkate alınarak yeniden güçlendirme bölgesi tasarımı gerçekleştirilmiş, plastik mafsal oluşumu akma bölgesi orta noktasına taşınmıştır.

- Çalışmada üretilen BÖÇ’ler içerdikleri detaylar gereği ilk defa Türkiye'de uygulaması yapılmış, yeni ve farklı yönleri olan BÖÇ'ler olup davranış özellikleri ileride yapılabilecek ek çalışmalarla daha da iyileştirilebilme potansiyeline sahiptir. $\mathrm{Bu}$ yapıldığında mevcut $\mathrm{Bu}$ çalışma ileride yeni çalışmaların yapılmasına temel oluşturma potansiyeline sahiptir.

\section{Semboller}

$A_{\text {con }} \quad$ : Çekirdek elemanın birleşim bölgesi enkesit alanı

$A_{s c} \quad$ : Çekirdek elemanın akma bölgesi net enkesit alanı 
$A_{t r} \quad$ : Çekirdek elemanın güçlendirme bölgesi enkesit alanı

$b_{y s c} \quad$ : Çekirdek elemanın akma bölgesi genişliği

$b_{\text {con }} \quad$ : Çekirdek elemanın birleşim bölgesi genişliği

$b_{t r} \quad$ : Çekirdek elemanın güçlendirme bölgesi genişliği

E $\quad$ : Elastisite Modülü

$E_{c} \quad$ : Dolgu malzemesi Elastisite Modülü

$E_{h} \quad$ : BÖÇ enerji yutma miktarı

$\left(f_{c}\right)_{28} \quad: 28$ günlük beton basınç dayanımı

$f_{c t k} \quad: 28$ günlük eğilmede beton çekme dayanımı

$F_{u} \quad$ : Çelik çekirdek kopma gerilmesi

$F_{y c} \quad$ : Çekirdek elemanın belirlenen minimum akma gerilmesini ya da kupon deneylerinden elde edilen gerçek akma gerilmesini

$K \quad$ : Çaprazın tahmin edilen etkin burkulma boyu katsayısı

$L \quad$ : Çapraz toplam uzunluk

$L_{\text {con }} \quad$ : Çaprazın birleşim bölgesi uzunluğu

$L_{t r} \quad$ : Çaprazın güçlendirme bölgesi uzunluğu

$L_{y c} \quad$ : Çaprazın maksimum akma bölgesi boyu

$P_{e} \quad$ : Euler burkulma yükü

$P_{\max } \quad$ : BÖÇ maksimum basınç kuvveti

$P_{y c} \quad$ : Çekirdek elemanın eksenel akma kuvveti

$R_{y} \quad:$ Malzeme dayanım faktörü

$t \quad$ : Çapraz çekirdek kalınlı̆̆ 1

$T_{\max } \quad$ : BÖÇ maksimum çekme kuvveti

$\beta \quad$ : Basınç dayanım düzeltme faktörü

$\Delta_{b y} \quad$ : Deney numunesinin ilk akmadaki eksenel yerdeğiştirme miktarı

$\varepsilon_{y} \quad$ : Çaprazın akma şekildeğiştirmesi

$\varepsilon_{u} \quad$ : Çaprazın maksimum uzama şekildeğiştirmesi

$\eta \quad$ : Kümülatif inelastik yerdeğiştirme

$v \quad$ : Poisson oran 1

$\xi_{\text {effb }} \quad$ : Etkili sönüm oranı

$\omega \quad$ : Çekme dayanımı düzeltme faktörü 


\section{Teşekkür}

Bu çalışma, İTÜ İnşaat Fakültesi Yapı ve Deprem Mühendisliği Laboratuvarında (STEEL), Türkiye Bilimsel ve Teknolojik Araştırma Kurumu (TÜBİTAK)-1002-110M776 ve İTÜBAP 33459 araştırma projelerinin sağladığı olanaklarla gerçekleştirilmiştir. Yazarlar malzeme-işçilik konularında destek sağlayan ÇIMTAŞ, FİBERFLON, KÖSTER, As Civata'ya teşekkürlerini sunarlar. Sistem deneyleri İTÜ Yapı ve Deprem Mühendisliği Laboratuvarında yapılmış, Boğaziçi Üniversitesi, İnşaat Mühendisliği Yapı Laboratuvarları çalışanlarından numunelerin üretiminde kısmen de destek alınmıştır. Tüm sonuçlar, öneriler yazarların sorumluluğunda olup destek veren kuruluşları ve kişileri bağlamamaktadır.

\section{Kaynaklar}

[1] Wakabayashi, M., Nakamura, T., Katagihara, A., Morisono, T. and Yokoyama, H., Experimental Study of the Elastoplastic Behavior of Braces Enclosed by Precast Concrete Panels Under Horizontal Cyclic Loading, Summaries of Technical Papers of Annual Meeting, Architectural Institute of Japan (AIJ), 1041-4, 1973.

[2] Kimura, K., Yoshioka, K., Takeda, T., Fukuya, Z., Takemoto, K., Tests on Braces Encased by Mortar in-filled Steel Tubes, Summaries of Technical Papers of Annual Meeting, Architectural Institute of Japan (AIJ), 1041-2, 1976.

[3] Watanabe, A., Hitomi, Y., Yaeki, E., Wada, A., Fujimoto, M., "Properties of brace encased in buckling-restraining concrete and steel tube", In: Proceedings of 9th world conference on earthquake engineering, Tokyo-Kyoto, Japan, 719-724, 1988.

[4] Gheidi, A., Mirtaheri, M., Zandi, A. P., Alanjari, P., "Effect of filler material on local and global behaviour of buckling-restrained braces", The Structural Design of Tall and Special Buildings, 10.1002/tal.555, 2009.

[5] Berman, J. W., and Bruneau, M., "Cyclic testing of a buckling restrained braced frame with unconstrained gusset connections", Journal of Structural Engineering, ASCE, 135(12), 1499-1510, 2009.

[6] Celik, O. C., Berman, J. W., Bruneau, M., "Cyclic testing of braces laterally restrained by steel studs", Journal of Structural Engineering, ASCE, 131(7), 1114-1124, 2005.

[7] Celik, O. C., Bruneau, M., "Skewed slab-on-girder steel bridge superstructures with bidirectional-ductile end diaphragms", Journal of Bridge Engineering, ASCE, 16(2), 207-218, 2011.

[8] Zhao, J., Wu, B., Li, W., Ou, J., "Local buckling behavior of steel angle core members in buckling-restrained braces: Cyclic tests, theoretical analysis, and design recommendations", Engineering Structures, 66, 129-145, 2014.

[9] Takeuchi, T., Matsui, R., Mihara, S., "Out-of-Plane stability assessment of bucklingrestrained braces with chevron configurations", 8th International Conference on Behavior of Steel Structures in Seismic Areas Shanghai, China, July 1-3, 2015.

[10] Fujishita, K, Bal, A, Sutcu, F, Celik, O. C., Takeuchi, T., Matsui, R., and Terashima, M., "Comparing hysteretic behavior of buckling restrained braces (BRBs) with bolted 
and welded end connections", In: 8th international symposium on steel structures (ISSS). Nov. 5-7, Jeju, Korea; 2015.

[11] Bazaez, R., Dusicka, P., "Cyclic behavior of reinforced concrete bridge bent retrofitted with buckling restrained braces”, Engineering Structures, 119, 34-48, 2016.

[12] Chou, C. C., Tsai, W. J., Chung, P. T., "Development and validation tests of a dualcore self-centering sandwiched buckling-restrained brace (SC-SBRB) for seismic resistance", Engineering Structures, 121, 30-41, 2016.

[13] Eryaşar, M. E., Topkaya, C., “An experimental study on steel-encased bucklingrestrained brace hysteretic dampers", Earthquake Engineering and Structural Dynamics, 39(5), 561-581, 2010.

[14] Bozkurt, M. B., Topkaya, C., "Development of welded overlap core steel encased buckling-restrained braces", Journal of Constructional Steel Research, 127, 151-164, 2016.

[15] Ozcelik, R., Dikiciasik, Y., Erdil, E. F., "The development of the buckling restrained braces with new end restrains" Journal of Constructional Steel Research, 138, 208-220, 2017.

[16] ASTM A 370-08a- Standard Test Methods and Definitions for Mechanical Testing of Steel Products, American Society for Testing and Materials, Philadelphia, PA, 2008.

[17] AISC 341-10- Seismic Provisions for Structural Steel Buildings, American Institute of Steel Construction AISC, Chicago, IL, 2010.

[18] AISC 360-10- Specification for Structural Steel Buildings, American Institute of Steel Construction, Chicago, IL, 2010.

[19] ANSI/AWS D1.1/D1.1M-Structural Welding Code-Steel, American Welding Society, Miami, 2008.

[20] Haydaroglu, C., Taskin, K., Celik, O. C., "Ductility enhancement of round HSS braces using CFRP sheet wraps", In: 6th european conference on steel and composite structures (Eurosteel), Budapest, Hungary, 2011.

[21] CSI SAP $2000 \mathrm{~V}-14$, Integrated software for structural analysis and design, analysis reference manual. Berkeley (CA): Computer and Structures Inc., 2009.

[22] FEMA-356- Prestandart and Commentary for the Seismic Rehabilitation of Buildings, In: Prepared by American Society of Civil Engineers for the Federal Emergency Management Agency, Washington (DC), 2000.

[23] Uang, C. M., Yu, Q. S., Gilton, C. S., "Effects of loading history on cyclic performance of steel RBS moment connections", Proceedings of the 12th WCEE, Upper Hutt, New Zealand, 2000. 